\title{
Platinum and Rhodium in Tagus Estuary, SW Europe: sources and spatial distribution
}

Carlos Eduardo Monteiro ${ }^{1,2 *}$, Margarida Correia dos Santos ${ }^{2}$, Antonio Cobelo-Garcia ${ }^{3}$, Pedro Brito ${ }^{1}$ and Miguel Caetano ${ }^{1}$

${ }^{1}$ IPMA-Portuguese Institute of Sea and Atmosphere, Division of Oceanography and Marine Environment, Av. Brasília, 1449-006 Lisbon, Portugal

2 Environmental Biogeochemistry, Centro de Química Estrutural, Instituto Superior Técnico, Universidade de Lisboa, Av. Rovisco Pais 1, 1049-001, Lisboa, Portugal

3 Bioxeoquímica Mariña, Instituto de Investigacións Mariñas IIM-CSIC, Eduardo Cabello 6, 36208 Vigo, Pontevedra, Spain

*Corresponding author: Carlos E. Monteiro:

carlos.monteiro@ipma.pt

carlos.e.monteiro@tecnico.ulisboa.pt

IPMA-Instituto português do Mar e da Atmosfera, Divisão de Oceanografia e Ambiente Marinho, Av. Brasília, 1449-006 Lisboa, Portugal

$+351218447000$

Centro de Química Estrutural, Instituto Superior Técnico, Universidade de Lisboa, Av. Rovisco Pais 1, Torre Sul Lab 11.6-2, 1049-001, Lisboa, Portugal

+351218419177 


\section{ABSTRACT:}

2 The spatial distribution of $\mathrm{Pt}$ and $\mathrm{Rh}$ was assessed in Tagus estuary and their sources

3 discussed. Both elements were analysed in superficial sediment samples $(n=72)$ by

4 adsorptive cathodic stripping voltammetry. Concentrations varied within the following

5 ranges: $0.18-5.1 \mathrm{ng} \mathrm{Pt} \mathrm{g}^{-1}$ and $0.02-1.5 \mathrm{ng} \mathrm{Rh} \mathrm{g}^{-1}$. Four distinct areas were established:

6 "reference"; waste- and pluvial waters discharge; motorway bridges and industrialised

7 areas. The calculated reference median concentrations were $0.55 \mathrm{ng} \mathrm{Pt} \mathrm{g}^{-1}$ and $0.27 \mathrm{ng} \mathrm{Rh}$

$8 \mathrm{~g}^{-1}$. Linear relationships were found between Pt and Al, Fe and LOI, whereas Rh depicted

9 scattered patterns. The highest concentrations were found nearby industrialised areas and

10 a motorway bridge, corresponding to the enrichment of 10 and 6 times the background of

$11 \mathrm{Pt}$ and $\mathrm{Rh}$, respectively. The main sources of contamination to the Tagus estuary derived

12 from historical and present industrial activities and from automotive catalytic converters.

13 Large variations of $\mathrm{Pt} / \mathrm{Rh}$ ratio (0.48-39) point to different sources, reactivity and dilution

14 effects. 
17 Keywords

18

19 Platinum-group elements

20 Spatial distribution

21 Superficial sediments

22 Tagus estuary

23 Anthropogenic contamination

24 
27 Technology-critical elements (TCE) are contaminants of environmental concern due to 28 increasing use in several technology-based sectors. Platinum-group elements (PGE) are part of the TCE and include platinum (Pt), palladium (Pd), rhodium (Rh), iridium (Ir), osmium (Os) and ruthenium $(\mathrm{Ru})$. Their global demand continues to rise despite the ultratrace concentrations found in the earth's upper continental crust (UCC) (Taylor and McLennan 1995; Peucker-Ehrenbrink and Jahn 2001; Ravindra et al. 2004).

Anthropogenic emissions of PGE have been largely attributed to the extensive use in automotive catalytic converters (ACC) (European Comission 1991; Kašpar et al. 2003). Platinum and $\mathrm{Rh}$ are included onto the ACC in the metallic or oxide forms. Due to degradation and mechanical abrasion during vehicle operation, they are released into the environment as fine grained particulate material (Ely et al. 2001; Moldovan et al. 2002; Ek et al. 2004; Rauch et al. 2002; Prichard and Fisher 2012; Zereini and Wiseman 2015). Regardless the emission rates of ng per kilometre per car (Ely et al. 2001), it has been observed the increase of $\mathrm{Pt}$ and $\mathrm{Rh}$ concentrations in road dust and roadside soils reaching

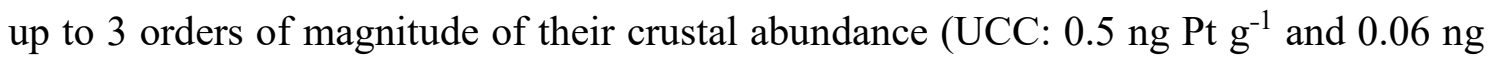
$\mathrm{Rh} \mathrm{g}^{-1}$ (Taylor and McLennan 1995; Peucker-Ehrenbrink and Jahn 2001; Zereini and Wiseman 2015). The mass $\mathrm{Pt} / \mathrm{Rh}$ ratio is often used to track different sources of $\mathrm{Pt}$ and $\mathrm{Rh}$. In particular, the typical range for ACC emissions varies between 5 - 16 (Ely et al. 2001; Ravindra et al. 2004; Rauch and Peucker-Ehrenbrink 2015). Additionally, shifts in the ratio may point to inputs of industrial activities and hospital effluents to the environment (Laschka and Nachtwey 1997; Rauch and Peucker-Ehrenbrink 2015). 
68

The increase of PGE concentrations in urban environments has been documented over the past years (Ek et al. 2004; Rauch et al. 2005, 2006; Zereini et al. 2004, 2007; Wiseman and Zereini 2009; Mihaljevič et al. 2013; Rauch and Peucker-Ehrenbrink 2015; Ruchter and Sures 2015; Wiseman et al. 2013, 2016; Birke et al. 2017). Studies dealing with spatially-resolved distribution provide useful information in the assessment of potential contamination sources to the aquatic systems. These studies in estuaries are mainly focused in Pt ( Terashima et al. 1993; Wei and Morrison 1994; Cobelo-García et al. 2011, 2013; Zhong et al. 2012) and very scarce information exists for Rh (e.g. Essumang et al. 2008). Most of the works focused on Rh center their research only in restricted areas or samples of estuarine systems (e.g. Essumang et al. 2008; Almécija et al. 2016a). Thus, the very limited research of $\mathrm{Pt}$ and $\mathrm{Rh}$ spatial distribution in river-estuarine systems exists to overcome the sinks and sources of these elements. We hypothesised that $\mathrm{Pt}$ and $\mathrm{Rh}$ contamination in Tagus estuary could be imprinted in superficial sediments because of the anthropogenic pressures and hydrodynamic of the estuary. Thus, we aimed (1) to quantify Pt and Rh concentrations in superficial sediments of the Tagus estuary; (2) to assess the influence of anthropogenic sources loading into the sediments; and (3) to define baseline patterns for future monitoring studies envisaging unknown PGE emissions to this aquatic system.

\section{Material and methods}

Study area 
71 Estuaries are very important in the interchange of mass between the land and the ocean.

72 The Tagus estuary (Fig. 1) is one of the largest in western Europe, with approximately $320 \mathrm{~km}^{2}$ comprising small islands, sand banks, and intertidal mudflats that account for $\sim 40 \%$ of the total area. The inner bay has approximately $25 \mathrm{~km}$ long and $15 \mathrm{~km}$ wide, and the bathymetry ranges between 0 and 7 meters' depth. Downstream, a narrow channel reaching $47 \mathrm{~m}$ depth and $2 \mathrm{~km}$ wide connects the estuary to the Atlantic Ocean (Fortunato et al. 1999; Freire et al. 2007; Taborda et al. 2009; Vaz et al. 2011).

The freshwater input to the Tagus estuary depends on rain events and it has its origin mainly from the Tagus river $\left(350 \mathrm{~m}^{3} \mathrm{~s}^{-1}\right.$, average annual flow), as well as from other small tributaries $\left(<35 \mathrm{~m}^{3} \mathrm{~s}^{-1}\right)$. The water circulation in Tagus estuary is mainly tidally driven, often considered mesotidal and vertically well-mixed (Vaz et al. 2011). Resuspension of particulate matter from sediments over the tidal cycling can occur due to wind forcing, rising tide, and water exchange with the main channels (Vale and Sundby 1987; Freire et al. 2007). Particle's settling occurs during the turnover of tides, depending on the current velocity and bathymetry. The particle resuspension-settling cycles in each semi-diurnal tide may play a key role on the scavenging of $\mathrm{Pt}$ and $\mathrm{Rh}$ to the sediments.

The Tagus estuary is well characterised with respect to the hydrodynamics (e.g. Vale and Sundby 1987; Fortunato et al. 1999; Vaz et al. 2011), trace elements (Vale et al. 2008; Santos-Echeandía et al. 2010; Caçador et al. 2012; Monteiro et al. 2016), persistent organic pollutants (Gil and Vale 1999; Mil-Homens et al. 2016), and nutrients (Cabeçadas 1999; Cabrita et al. 1999; Mateus and Neves 2008). For PGE, only data on Pt, Rh and Os were reported before in spot areas of the estuary and coastal sediments (Cobelo-García et al. 2011; Almécija et al. 2015, 2016a, 2016b), pointing to anthropogenic inputs. The Tagus estuary (Fig. 1) has particular features that makes it a natural setting for the study of these elements. The anthropogenic pressures result from heavily industrialised areas, 
with historical and present-day activities. At the southern margin exits a metallurgic complex (SN), a chemical complex (BRR) with a large area decommissioned, and an inactive shipyard (LN). At the northern margin operates a chemical industrial unit (CN) and the denser urban area is settled. Intense urban sprawl reaches 2.8 million of inhabitants around the estuary (Costa 2016) with several Waste Water Treatment Plants (WWTP) and pluvial water drainage channels dispersed in the margins. Three major WWTP exist in the northern margin: Alcântara (A), Beirolas (B) and Chelas (C); and at Terreiro do Paço (TP) is located one of the main channels for the pluvial runoff. Moreover, the Tagus estuary is crossed by two high traffic motorway bridges, Vasco da Gama (VG bridge) and 25 de Abril (25A bridge), where 175000 - 225000 vehicles pass every day (IMT 2016).

Sediment samples collection and preparation

Taking into account potential sources of $\mathrm{Pt}$ and $\mathrm{Rh}$ to the Tagus estuary, superficial sediment samples $(<5 \mathrm{~cm}$ depth) were collected in 72 stations on-board of a small vessel using a Van Veen grab sampler. A set of samples $(n=12)$ was collected in 2015 at the waste- and pluvial waters effluents (A, B, C and TP, in Fig. 1). In addition, two control samples were collected upstream (-U) and downstream (-D) of each effluent, spaced by approximately $0.5-1 \mathrm{~km}$. Another set of superficial sediments $(\mathrm{n}=60)$ was sampled in June 2016, following a spatial grid covering the immersed area of the estuary. Emphasis on VG bridge influence area was preferred since it was not feasible to collect samples nearby $25 \mathrm{~A}$ bridge, due to the higher current velocity and coarser sediments (rocks, gravel and coarse sand) than in the rest of Tagus estuary (Fig. 1). 
120 Sediment samples were dried in an oven at $40{ }^{\circ} \mathrm{C}$. After homogenisation, aliquots were

121 separated for grain size analysis and after sieving $(<2 \mathrm{~mm})$ another portion was ground 122 to a fine powder for further analyses.

123

124 Analytical procedures

125

126 Material and chemicals

127

128 All laboratory material used was acid-cleaned by successive immersion periods of 48 129 hours in $\sim 20 \%$ nitric acid $\left(\mathrm{HNO}_{3}\right)$ followed by $\sim 20 \%$ hydrochloric acid $(\mathrm{HCl})$. 130 Afterwards, the material was rinsed with Milli-Q water (18.2 M $\left.2 . \mathrm{cm}, 25^{\circ} \mathrm{C}\right)$ and let to 131 dry in a clean room. All reagents used throughout the work were always of high-purity 132 grade, either for samples digestion or analysis: hydrofluoric acid (HF) $40 \%, \mathrm{HNO}_{3} 65 \%$ 133 and $\mathrm{HCl} 30 \%$ (Suprapur, Merck), sulphuric acid $\left(\mathrm{H}_{2} \mathrm{SO}_{4}\right) \geq 95 \%$ (TraceSELECT, 134 Fluka), hydrazine sulphate (HZ; p.a., Fluka) and formaldehyde 13 M (FA $36.5 \%$, Riedelde-Haen). Diluted standards of $1.0 \mu \mathrm{g} \mathrm{Pt} \mathrm{L} \mathrm{L}^{-1}$ and $1.0 \mu \mathrm{g} \mathrm{Rh} \mathrm{L}^{-1}$ in $0.1 \mathrm{M} \mathrm{HCl}$ were weekly 136 prepared from standard solutions of $\mathrm{Pt}$ and $\mathrm{Rh} 1000 \mathrm{mg} \mathrm{L}^{-1}$ (TraceCERT, Fluka). Other 137 solutions were prepared in Milli-Q (18.2 M $\Omega . \mathrm{cm})$ water and kept in perfluoroalkoxy 138 flasks. 
142 Grain size analysis was carried out in sediments by dry sieving (Gaudêncio et al. 1991).

143 According to Folk (1954), three classes of sediment grain sizes (\%) were used to evaluate

144 the contents of gravel $(\geq 2 \mathrm{~mm})$, sand $(2-0.063 \mathrm{~mm})$, and the finer fraction corresponding

145 to silt and clay $(<0.063 \mathrm{~mm})$. Organic matter was determined on the basis of Loss-on-

146 Ignition (LOI, in \%), estimated by the weight difference of dried samples at $105{ }^{\circ} \mathrm{C}$ and

147 heated at $450{ }^{\circ} \mathrm{C}$ in a muffle furnace for $2 \mathrm{~h}$ (Craft et al. 1991). The temperature used in

148 this procedure ensures that the sediment carbonate fraction was unchanged.

Major elemental composition

Major elemental composition of the sediments (total $\mathrm{Al}, \mathrm{Fe}, \mathrm{Mn}, \mathrm{Mg}$ and $\mathrm{Ca}$ ) was quantified in $\approx 0.1 \mathrm{~g}$ (dry weight, d.w.) aliquots after a two steps digestion. Complete dissolution was achieved using a mixture of $1 \mathrm{~mL}$ of aqua regia (a mixture of $\mathrm{HCl}: \mathrm{HNO}_{3}$; 3:1) and $3 \mathrm{~mL}$ of $\mathrm{HF}(40 \%)$, at $100{ }^{\circ} \mathrm{C}$ for $1 \mathrm{~h}$ in closed Teflon autoclaves (Loring and Rantala 1992). The resultant solution was evaporated to near dryness in Teflon vessels (DigiPrep HotBlock-SCP Science), re-dissolved with $1 \mathrm{~mL}$ of distilled $\mathrm{HNO}_{3}$ and $5 \mathrm{~mL}$ of Milli-Q water, heated for $20 \mathrm{~min}$ at $75^{\circ} \mathrm{C}$ and diluted in Milli-Q water to a final volume of $50 \mathrm{~mL}$ (Caetano et al. 2009). Inductively coupled plasma - mass spectrometry (ICPMS) was used to determine major elemental composition of the sediments. The determinations were done in quadrupole ICP-MS from Thermo Elemental (X-Series), equipped with a concentric Meinhard nebulizer and a Peltier impact bead spray chamber, following the procedure previously reported Brito et al. (2018). Main experimental parameters were as follows: forward power $1400 \mathrm{~W}$; peak jumping mode; 150 sweeps per replicate; dwell time of $10 \mathrm{~ms}$; dead time of $30 \mathrm{~ns}$. 
Pt and Rh determination

169 For the determination of Pt and $\mathrm{Rh}$ in the sediments the procedures of Nygren et al. (1990) and of Haus et al. (2009) were followed for samples digestion. Sediment samples of $\approx 0.2$ $\mathrm{g}$ of each were heated in quartz crucibles up to $800^{\circ} \mathrm{C}$ in a muffle furnace. After cooling,

172 samples were transferred to PFA pressurised digestion vessels (MarsXpress, CEM) and 173 they were microwave-assisted digested in the presence of $4 \mathrm{ml}$ of aqua regia. Afterwards, samples were evaporated to near dryness at $85^{\circ} \mathrm{C}$ in a hot plate, re-dissolved in $1 \mathrm{~mL}$ of $\mathrm{H}_{2} \mathrm{SO}_{4}$, and were left to evaporate the residual acids until constant volume. Finally the residue was transferred to polypropylene Digitubes (SCP Science) and diluted to $25 \mathrm{~mL}$ in $0.1 \mathrm{M} \mathrm{HCl}$. Adsorptive Cathodic Stripping Voltammetry (AdCSV) was used for the determination of $\mathrm{Pt}$ and $\mathrm{Rh}$, following the procedure optimised by Monteiro et al. (2017).

179 Briefly, the voltammetric measurements were carried out in an acclimatized room at 25 $\pm 2{ }^{\circ} \mathrm{C}$. A potentiostat/galvanostat from ECO Chemie, Autolab PGSTAT $128 \mathrm{~N}$ (Metrohm), was used as the source of the applied potential and as the measuring device, connected to the Metrohm Stand 663. A conventional three-electrode configuration was used: a Static Mercury Drop Electrode (SMDE) as the working electrode, an $\mathrm{Ag} / \mathrm{AgCl} / \mathrm{KCl}_{\text {(sat) }}$ as the reference electrode (placed inside a salt bridge with $3 \mathrm{M} \mathrm{KCl}$ ) and a carbon rod as auxiliary electrode. The whole system was controlled and data analyzed with the GPES v4.9 software (EchoChemie). The standard addition method was used to quantify Pt and Rh concentrations (Monteiro et al. 2017). All measurements were done at least in triplicate. 
Quality control of the analytical procedures

191

192 The quality control on major elements determination was assessed by running a multi193 element solution in every 10 samples. Coefficients of variation for metal counts $(n=3)$ were $<2 \%$. Certified reference materials (CRM) MAG-1, G-2, and BHVO-1 (USGS), with different matrices, were used to control the analytical procedure. The results obtained did not differ significantly $(\mathrm{p}>0.05)$ from the certified values. Procedural blanks always accounted for $<1 \%$ of total concentrations in samples (Brito et al. 2018).

For Pt and Rh determinations, the accuracy was evaluated through the recoveries (\%) in digested CRM road dust BCR-723 (EC-JRC-IRMM). Recoveries were $92 \pm 11 \%$ for Pt and $85 \pm 13 \%$ for $\mathrm{Rh}(\mathrm{n}>10)$, which were within the certified ranges. Procedural blanks $(n>10)$ were analysed to evaluate potential cross contamination. The average limits of

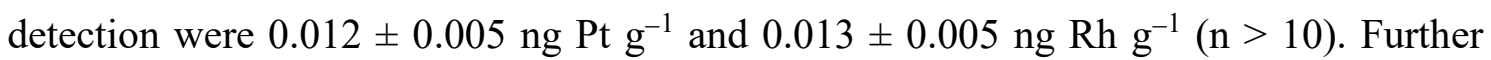
details are fully described in Monteiro et al. (2017).

Data processing

All statistical analysis was performed using XLSTAT (Addinsoft). Normality of the data was assessed using the Shapiro-Wilk test. Since most of the variables did not present normal distribution, non-parametric Kruskal-Wallis (H) test was applied to assess the differences in median values, with post hoc test. In addition, Mann-Whitney (U) test was also applied to assess significant differences between groups. Grubbs test was used to 
212 check the data for outliers. In addition, Spearman rank correlations $\left(r_{s}\right)$ were also computed to evaluate trend relationships (Miller and Miller 2010).

214 Images of the spatial distributions were generated using the Ocean Data View software 215 (ODV; Schlitzer 2017) using Data Interpolating Variational Analysis (DIVA) method.

216 This method takes into account topographic and dynamic constraints when generating 217 grids based on a relative low number of observations (Troupin et al. 2012). However, boundary conditions were superimposed in ODV/DIVA by delimiting the area of interest of the Tagus estuary, with better resolution in the rough edges of the estuary in order to improve interpolations.

\section{Results}

Characterisation of superficial sediments

Sediment samples from Tagus estuary were characterised for grain-size, LOI and major elemental composition. Descriptive statistics of the data are summarised in Table 1. The median value of the sand fraction $(2-0.063 \mathrm{~mm})$ was $41 \%$ and in general lower than the fine-sized fraction $(<0.063 \mathrm{~mm})$ that corresponds to silt and clay material (Table 1). The contents of $\mathrm{Al}, \mathrm{Fe}$, and LOI ranged up to $\sim 10 \%$, and the higher levels were associated with deposits of fine-grained material in the northern margin and mudflats of the upper and middle estuary. Magnesium and Mn were below 1.4 and $0.71 \%$, respectively, with no clear distribution pattern within the estuary. Calcium ranged up to $7.1 \%$ and the highest concentrations were found in samples containing fragments of bivalve shells. 
Concentrations and spatial distribution of $\mathrm{Pt}$ and $\mathrm{Rh}$

The concentrations of $\mathrm{Pt}$ and $\mathrm{Rh}$ in superficial sediments from the Tagus estuary varied between $0.18-5.1 \mathrm{ng} \mathrm{Pt} \mathrm{g}^{-1}$ and $0.02-1.5 \mathrm{ng} \mathrm{Rh} \mathrm{g}^{-1}$ (d.w.) (Fig. 2), being the median values $0.60 \mathrm{ng} \mathrm{Pt} \mathrm{g}{ }^{-1}$ and $0.54 \mathrm{ng} \mathrm{Rh} \mathrm{g}^{-1}$ (Fig. 3a).

Based on the potential sources to the estuary and spatial distribution of both elements, four estuarine sections were outlined for further discussion (Fig. 3): (i) "reference concentration" of $\mathrm{Pt}$ and $\mathrm{Rh}$ that comprises the stations distant from potential sources;

(ii) waste- and pluvial waters discharge sites in the northern margin; (iii) motorway bridges, in particular VG bridge; and (iv) industrialised areas, corresponding to sites BRR, SN, LN and CN. Differences on median values among groups were observed, being significantly different for $\mathrm{Pt}(\mathrm{H}(3, \mathrm{n}=72)=20.30, \mathrm{p}<0.001)$ and for $\mathrm{Rh}(\mathrm{H}(3, \mathrm{n}=72)=$ 7.867, $\mathrm{p}<0.05$ ). When comparing paired-sections (Mann-Whitney (U) test), the industry section was significantly different from the other sections $(p<0.05)$ (Fig. 3b) in the case of Pt. Although at VG bridge have been found higher values up to 6 times than in WWTP and reference sections, the broad interval of variation lead to no significant differences between sections $(p>0.05)$. In the case of $R h$, no significant differences were found between the reference, WWTP and industry sections ( $p>0.05)$ (Fig. 3c). Other statistical similarities found were those of WWTP section with VG bridge and industry sections $(p>0.05)$ and between VG bridge and industry sections $(p>0.05)$. However, the lack of statistical differences for Rh between industry and the other sections is largely dependent on the low concentrations found at BRR than in the other industrial sites (Fig. 3d). 
262 The lowest concentrations of $\mathrm{Pt}$ and $\mathrm{Rh}$, up to the median values, were found mostly in the central areas of the estuary. Considering only the stations far from possible anthropogenic sources as reference stations, levels of Pt ranged from $0.18-1.5 \mathrm{ng} \mathrm{g}^{-1}$ (d.w.) with a median of $0.55 \mathrm{ng} \mathrm{g}^{-1}$. For Rh concentrations varied within $0.02-1.3 \mathrm{ng} \mathrm{g}^{-1}$ (d.w.) with a median of $0.27 \mathrm{ng} \mathrm{g}^{-1}$.

It was found in those stations a clear affinity of $\mathrm{Pt}$ for $\mathrm{Al}, \mathrm{Fe}$ and LOI, with significant regressions (Fig. 4). When normalised, the spatial distribution of $\mathrm{Pt} / \mathrm{LOI}$ and $\mathrm{Pt} / \mathrm{Fe}$ (Fig. 5) resulted in a wider spread of Pt signature than that observed for Pt/Al. No significant correlations ( $p>0.05$ ) were found between $\mathrm{Rh}$ concentrations and the content of $\mathrm{Al}, \mathrm{Fe}$ and LOI (Fig. 4).

Waste- and pluvial waters discharge

Relatively low concentrations of $\mathrm{Pt}$ and $\mathrm{Rh}$ were observed in the discharge sites of wasteand pluvial waters at the northern margin (A, B, C and TP, in Fig. 1). Concentrations of both metals were closer to the reference levels of the Tagus estuary, ranging from 0.23 -

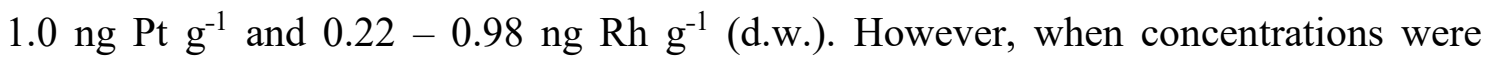
normalized to Al or LOI, sediment levels from the discharge sites of Alcântara (A) and Beirolas (B) WWTP were higher than the values found in upstream and downstream control stations (A-U, B-U and A-D, B-D, respectively; Fig. 6). This trend was not found 
282 for WWTP of Chelas (C) and the pluvial waters discharge site at Terreiro do Paço (TP), presumably due to their low discharge into the estuary.

Anthropogenic point sources and signature in sediments

286

287 Concentrations of both elements increased downstream of the VG bridge and in both margins closer to the bridge ends, varying from $0.22-3.0 \mathrm{ng} \mathrm{Pt} \mathrm{g}^{-1}$ and from $0.12-1.1$ $n g \mathrm{Rh} \mathrm{g}^{-1}$ (d.w.). Furthermore, the highest levels were found closer to the industrialised areas (Fig. 3 and S.I. Fig. 1). Platinum concentrations (d.w.) were $1.8 \mathrm{ng} \mathrm{g}^{-1}$ at LN, $2.5 \mathrm{ng}$ $\mathrm{g}^{-1}$ at $\mathrm{SN}, 2.7 \mathrm{ng} \mathrm{g}^{-1}$ at $\mathrm{CN}$ and up to 3.5-5.1 $\mathrm{ng} \mathrm{g}^{-1}$ at BRR sites. Regarding Rh levels, they varied between 1.2 and $1.5 \mathrm{ng} \mathrm{g}^{-1}$ at $\mathrm{LN}, \mathrm{SN}$ and $\mathrm{CN}$, but lower values were found at $\mathrm{BBR},<0.01-0.13 \mathrm{ng} \mathrm{g}^{-1}$.

In the Tagus estuary, Pt/Rh ranged within 2 orders of magnitude, between 0.48 and 39

(Fig. 7). The lowest $\mathrm{Pt} / \mathrm{Rh}$ ratio corresponded to the reference signature, varying between 0.48 and 4.0 and with a median value of 1.6 (all reference stations). If it is only considered the innermost stations of the Tagus Natural Reserve area, where no direct anthropogenic activities exist, then the range of $\mathrm{Pt} / \mathrm{Rh}$ decreases to a median value of 0.9 . Similar to that reference value, the signature of particles derived from the WWTP stations was low (0.6 - 1.6). In sediments closer to VG bridge, values were in general higher than the reference section (0.9), ranging from 0.5 to 5.6. Additionally, a road dust sample was collected in

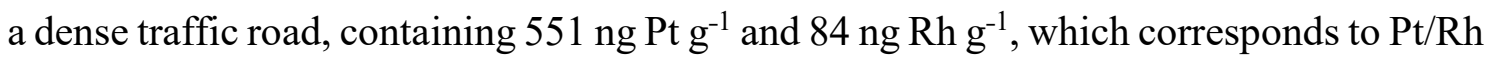
of 6.6. The largest difference on $\mathrm{Pt} / \mathrm{Rh}$ mass ratio (1.5 - 39) was observed in industrialised areas. At BRR it was found the highest $\mathrm{Pt} / \mathrm{Rh}$ values $(25-39)$, while in other industrial sites $\mathrm{Pt} / \mathrm{Rh}$ values were low $(1.5-2)$. 
Discussion

308 The reference value of $\mathrm{Pt}$ concentration in Tagus estuary $\left(0.55 \mathrm{ng} \mathrm{g}^{-1}\right)$ is similar to the 309 concentration in the Upper Continental Crust (UCC, $0.5 \mathrm{ng} \mathrm{Pt} \mathrm{g}^{-1}$; Taylor and McLennan 1995; Peucker-Ehrenbrink and Jahn 2001; Ravindra et al. 2004). Furthermore, that value is comparable to the baseline concentration in shelf sediments of the Tagus in the sediment horizon corresponding to 1920, found by Cobelo-Garcia et al. (2011). This was not found for Rh since the estimated reference level in Tagus estuary sediments $(0.27 \mathrm{ng}$ $\left.\mathrm{g}^{-1}\right)$ was 4 times higher than the value indicated for the UCC (0.06 ng Rh g $\mathrm{g}^{-1}$; Taylor and McLennan 1995) and also for the deepest layers of a salt marsh core, reported by Almécija et al. (2016a). The concentrations of Pt in Tagus estuary sediments $\left(0.18-5.1 \mathrm{ng} \mathrm{g}^{-1}\right)$ are in the range of those reported by Zhong et al. (2012) for the Pearl River estuary, China, Wei and Morrison (1994) for three urban river sediments in Gothenburg, Sweden, and Prichard et al. (2008) in Humber estuary, UK. However, levels of this element in Tagus are lower than those found by Ruchter and Sures (2015) in the river Alb, Germany (up to $45 \mathrm{ng} \mathrm{Pt} \mathrm{g}^{-1}$ ) or by Sutherland et al. (2015) in the bed sediments of Nuuanu stream, Hawaii - $1.5 \mathrm{ng} \mathrm{g}^{-1}$ ) is comparable to those reported by Sutherland et al. (2015) for in Hawaii $\left(0.32-3.5 \mathrm{ng} \mathrm{g}^{-1}\right)$ or by Prichard et al. (2008) for the Humber estuary, UK (1 - $\left.2 \mathrm{ng} \mathrm{g}^{-1}\right)$.

Variation of the reference levels in the estuary

Low concentrations of $\mathrm{Pt}$ and $\mathrm{Rh}$ were observed in the central areas of the Tagus estuary, ranging from $0.18-1.5 \mathrm{ng} \mathrm{Pt} \mathrm{g}^{-1}$ and $0.02-1.3 \mathrm{ng} \mathrm{Rh} \mathrm{g}^{-1}$ (d.w.). In order to minimize the 
anthropogenic contributions of these elements (Dung et al. 2013), the variation of Pt and $\mathrm{Rh}$ in reference stations was assessed in sediments far from potential sources by evaluating the relationships with the ancillary parameters. Aluminium content is usually used due to the conservative behaviour and rare anthropogenic inputs, being a proxy for particle's nature in sediments (Loring and Rantala 1992; Matys Grygar and Popelka 2016). However, using Al-normalised metal concentrations is not straightforward and other parameters may be used, like Fe and organic matter (Matys Grygar and Popelka, 2016). The affinity of $\mathrm{Pt}$ towards $\mathrm{Al}, \mathrm{Fe}$ and LOI indicates that its distribution in sediments is governed by the sediment characteristics or by a group of several parameters, contrarily to Rh. A clear affinity of Pt to the fine-sized fraction (silt and clay) of the sediments was observed, but not for $\mathrm{Rh}$. Thus, the transport of $\mathrm{Pt}$ and $\mathrm{Rh}$ within the estuary is likely to be differently affected by the nature of particulate material in association with the hydrodynamic regime of the estuary.

Different contribution of both margins on the sediment loadings is due to geologic features and intense, yet dissimilar, anthropogenic pressures (Taborda et al. 2009). The reference levels of Pt and Rh in the Tagus estuary may derive from weathering of NeoCretaceous basalts and pyroclasts from the Lisbon Volcanic Complex (Prudêncio et al. 1993; Taborda et al. 2009). The higher contribution yielded by the southern margin sediments includes sandstones, sand, gravel, silt and clay from detrital Plio-Pleistocene that constitute the fluvial terraces, resulting mainly from erosion (Taborda et al. 2009). In addition, pyrite is the main group of minerals responsible for a background signature of PGE. However, the reference levels may be influenced by specific anthropogenic activities in the Tagus, such as different types of industry. The implementation of a chemical plant in the southern margin of the estuary that operated during the XX century (1909-1990s) included a pyrite-roasting unit and a smelter. During this period, the 
355 industry used pyrite from Lousal and Aljustrel mines, both part of the Iberian Pyrite Belt

356 (Mil-Homens et al. 2013). This raw material was stored in large piles in the southern

357 margin of the estuary and could cause the spread of particulate material containing PGE

358 in a large area, including the estuary. Thus, the input of this geological material for such

359 a long period could mask the background $\mathrm{Pt}$ and $\mathrm{Rh}$ values existing in the original

360 minerals from the Tagus river basin.

361

362 Sources and distribution of $\mathrm{Pt}$ and $\mathrm{Rh}$

Waste- and pluvial waters discharge sites

The concentrations of Pt and $\mathrm{Rh}$ found in sediments closer to the WWTP outfalls were within the range of reference levels in Tagus estuary. However, the increased signal in stations $\mathrm{A}$ and $\mathrm{B}$, after normalization to $\mathrm{Al}$ and/or LOI, reflects the drainage of a large urban area for a considerable period of time, from Lisbon, which mainly includes domestic and hospital effluents, and pluvial runoff. The presence of Pt-based anticancer drugs was recently reported in sewage and wastewaters (Vyas et al. 2014). These authors did not find evident relationships between the administered quantities of Pt and measured concentrations in drainage, reflecting the randomness of the excreted Pt. Furthermore, Monteiro et al. (2017) showed that an increase in dissolved Pt concentrations was detected in the effluents of the WWTP. During the water treatment along the WWTP, dissolved Pt concentrations reduced to half while dissolved Rh was kept invariable. Although low dissolved concentrations of $\mathrm{Pt}$ and $\mathrm{Rh}\left(\mathrm{ng} \mathrm{L}^{-1}\right)$ are introduced in the estuary through the WWTP, the input of high volume of water $\left(3-100 \mathrm{~m}^{3} \mathrm{~s}^{-1}\right)$ results in a detectable imprint 
379 in sediments $\left(\mathrm{ng} \mathrm{g}^{-1}\right)$. Furthermore, coupling other elements with Pt or Rh can be of major

380 interest to track anthropogenic emissions of technology-critical elements. In fact, rare

381 earth elements (REE) do support the transfer of urban contamination from different

382 anthropogenic sources into the Tagus estuary. Brito et al. (2018) observed this signature

383 for some of the REE at the same WWTP stations, e.g. Gd (S.I. Fig. 2) and Ce, which

384 suggests the association of metals to the particulate load from urban effluents and runoff material. Despite having distinct point sources, their pathways into the estuary are in general the same. Along with $\mathrm{Pt}, \mathrm{Gd}$ can be used to track anthropogenic contamination with source in medical applications (Ebrahimi and Barbieri, 2019). In addition, Wiseman et al. (2016) used Ce coupled to Pt, Rh and Pd to evaluate ACC emissions in roadside soils from Toronto, Canada.

Motorway bridges

Both $\mathrm{Pt}$ and $\mathrm{Rh}$ followed the same spatial distribution pattern with increasing levels downstream of VG bridge. Furthermore, a clear input was also found in the north margin at the bridge end. These results point that both elements have the same anthropogenic source, with these signatures of $\mathrm{Pt}$ and $\mathrm{Rh}$ most likely resulting from the abrasion and degradation of ACC. This particular spatial distribution may derive from the concrete structure of the VG bridge. The road dust material accumulates along the bridge during the dry season and then is flushed directly to the estuary during rain periods through a system of gully pots. The road dust enters the estuary at several points located along the bridge and is spread according to the tidal and hydrodynamic regime. The spreading of 
semidiurnal cycles. The bridge is located approximately in the maximum turbidity zone

404

405

406

407

408

409

410

411

412

413

414

415

416

417

418

419

420

421

422

423

424

425

426

427

of the estuary and major mixture of freshwater and seawater occurs towards the estuary mouth. In a previous study, Almécija et al. (2016b) found elevated concentrations of Pt (40 $\left.\mathrm{ng} \mathrm{g}^{-1}\right)$ in surface sediments from a system of channels and creeks in a salt marsh at the southern margin. In these ecosystems, particulate material including road dust is retained by halophyte plants and deposited in low hydrodynamic areas.

It should be pointed out that it was not feasible to collect samples in the surroundings of $25 \mathrm{~A}$ bridge. Low sedimentation rate in the bridge area is due to the narrow connection to the sea, where higher depth (up to $47 \mathrm{~m}$ ) and current velocity (up to $2.0 \mathrm{~m} \mathrm{~s}^{-1}$ ) are observed than in the rest of the estuary, and the nature of bottom substrate is mainly rock gravel. These characteristics coupled with the bridge structure do not favour a localised deposition site. This bridge has a gridded metallic deck that allows rainwater and road dust particles to pass through, without a channelled drainage system. It has a navigation clearance height of $70 \mathrm{~m}$ above the water level in comparison with the $14 \mathrm{~m}$ of VG bridge. Thus, 25A bridge it is more exposed to environmental conditions than VG bridge, such as strong winds. All these characteristics result in a wider spread of road dust. Therefore, it is hypothesised that no clear signatures of $\mathrm{Pt}$ and $\mathrm{Rh}$ from this source could be found in sediments.

The input of both elements through the motorway bridges can be estimated based on traffic and structural characteristics. It is noteworthy that regardless the higher traffic density in $25 \mathrm{~A}$ bridge, three times higher $\left(\approx 150000\right.$ cars $\left.^{-1}\right)$ than in VG bridge, Pt and Rh estimated emissions from ACC were lower. The estimated total emissions since the opening of VG bridge in 1998 ranged from $542-937 \mathrm{~g}$ of Pt and $130-262 \mathrm{~g}$ of Rh. Furthermore, if we calculate Pt emissions per year on VG bridge, we found that our lower value is $\approx 30 \mathrm{~g} \mathrm{Pt}^{-1}$ (542 $\mathrm{g} \mathrm{Pt} / 18.1$ years), which is comparable to the $\approx 33 \mathrm{~g} \mathrm{Pt}^{-1}$ (450 
g Pt /13.6 years) estimated by Almécija et al (2015) using the same approach. This

429

430

431

432

estimation may vary due to the different sedimentation rates found along the $\sim 17 \mathrm{~km}$ of the VG bridge that crosses the larger section of the Tagus estuary. For the 25A bridge a lower interval of emissions was found, $171-312 \mathrm{~g}$ of Pt and $41-87 \mathrm{~g}$ of Rh (further details in S.I. Table A-1). Even with higher vehicle traffic on $25 \mathrm{~A}$ bridge than in VG bridge, it is clear that their extension plays a major role in the estimated emissions of $\mathrm{Pt}$ and Rh from ACC.

Industrialised areas

The levels of Pt and Rh at stations BRR, SN, LN, and CN (circles in Fig. 1) point to local anthropogenic sources. The concentrations correspond to an increase up to $10(\mathrm{Pt})$ and 6 (Rh) times the reference levels estimated in the estuary.

The increase of Pt in BRR superficial sediments may suggest a recent point source, which could be explained by the current production of fertilizers or the historical slags in the area exposed to the atmospheric conditions. The chemical-industrial complex at BRR had a long history in the production of nitric and sulphuric acids, and fertilizers, which may have used Pt as catalyst (e.g. Hatfield et al. 1987), with peak activity around the 1960s and early 1970s. The pyrite ore processing used to extract $\mathrm{Cu}, \mathrm{Pb}, \mathrm{Au}$, and $\mathrm{Ag}$, may have also contributed to that increase. The particulate material from the exposed piles of pyrite slag could be transported easily into the estuary through the air or drainage channels in the margin. However, Rh concentrations were very low. Metal contamination patterns from BRR industrial activities were previously reported for $\mathrm{Hg}$ (Canário et al. 2005), Cd, 
$451 \mathrm{~Pb}, \mathrm{Ni}$ and As (Vale et al. 2008), and more recently for the YREE, e.g. Y (Brito et al. 452 2018). Thus, BRR site may be a hotspot for PGE and further research is ongoing.

453 Part of the slag at BRR was transferred to another industrial complex and used as raw

454 material in metallurgical industry. This unit located also in the southern margin of the 455 Tagus (SN site) continues to operate producing steel and treating slag residues. At this 456 unit, the increased $\mathrm{Rh}$ concentrations suggest that $\mathrm{Rh}$ was more mobilized to the aquatic 457 environment compared to Pt.

458 Another anthropogenic source of both PGE was found at the LN site, currently a 459 dismantled shipyard but fully operating in the 1960s and early 1970 s. By that time, $30 \%$ of the world tanker fleet was repaired in this shipyard that included a variety of iron and steel works, releasing large amounts of metallic residues. The former activity coupled with the remaining of such large and abandoned infrastructures could be responsible for the $\mathrm{Pt}$ and $\mathrm{Rh}$ input to the sediments. Considering the peak activity of the chemicalindustrial complex at BRR and the shipyard at LN, Pt and Rh emitted to the Tagus estuary must have been larger than those estimated in this study. The industrial activity at BRR decreased after dismantling the acid production and pyrite processing units almost two decades ago. Thus, levels in superficial sediments suggest continuous input from the fertilizer unit currently operating and/or mobility of Pt within the sedimentary column.

In the northern margin, $\mathrm{Pt}$ and $\mathrm{Rh}$ concentrations found at the $\mathrm{CN}$ site are likely related to the chemical industry operating for more than half of a century. A chlor-alkali industry uses a catalytic hydrogenation process based on PGE non-supported or supported catalysts (e.g. on silica or alumina; Paparatto et al. 2010; Lemaire et al. 2014). The 473 degradation of the catalyst releases $\mathrm{Pt}$ and $\mathrm{Rh}$ that may reach the estuary through the 474 industrial effluent. The narrow estuary channel where this unit is located has lower current 
475

476 bottom sediments. Furthermore, the concentration of Rh found at $\mathrm{CN}$ site was the highest

477 in the entire estuary, suggesting its use as a catalyst, as well as Pt. Moreover, relatively high concentrations of some of the REE were also observed at this site (Brito et al. 2018). In addition to the previously reported contamination by $\mathrm{Hg}$ (Cesário et al. 2016), Pt, $\mathrm{Rh}$ and REE underpin the industrial point sources of contamination in Tagus estuary.

\section{Signature of Pt and Rh in sediments}

Platinum and Rh sources are often assessed through the Pt/Rh mass ratio (e.g. Sutherland et al. 2015). This ratio variability relies on different sources, such as industrial or hospital effluents than on changes of ACC's composition (Ruchter et al. 2015). Biogeochemical processes in the water column or in bottom sediments may also affect $\mathrm{Pt}$ and $\mathrm{Rh}$ differently due to their different reactivity (Jarvis et al. 2001). Lower Pt/Rh values obtained on reference stations do not strictly represent a background because of the atmospheric input of material and tidal transport of particles from other estuarine areas. By shifting the concentration of one element, either Pt or Rh due to an additional source, this mass ratio can vary considerably. In WWTP section, the low values found may suggest that Pt signature derived from hospital and domestic effluents may be masked by dilution from the drainage system and/or additional Rh sources, such as those from ACC.

In sediments closer to VG bridge, $\mathrm{Pt} / \mathrm{Rh}$ reflect mainly the ACC contribution. This section presented larger variations in the $\mathrm{Pt} / \mathrm{Rh}$ ratio, having values within the typical range reported for ACC (Ely et al. 2001; Ravindra et al. 2004; Rauch and Peucker-Ehrenbrink 2015). Additionally, the road dust sample collected in a dense traffic road presented $\mathrm{Pt} / \mathrm{Rh}$ 
mass ratio of 6.6.Thus, the variable $\mathrm{Pt} / \mathrm{Rh}$ signature in sedimentary material closer to the

500 VG bridge indicates that different dilution/concentration effects masking the real ACC signature may occur. At the estuary margins, around the VG bridge, a dilution effect exists due to the input of Pt and Rh from urban sources decreasing the signature. During the transport of road dust to the estuary, the partition of $\mathrm{Pt}$ or $\mathrm{Rh}$ may change and shift the ratio $\mathrm{Pt} / \mathrm{Rh}$. This suggests $\mathrm{Pt}$ and $\mathrm{Rh}$ in the Tagus estuary have a common source in ACC emissions from urban areas.

The highest $\mathrm{Pt} / \mathrm{Rh}$ mass ratio observed in BRR sediments, compared to the other industrial sites (CN, $\mathrm{SN}$ and $\mathrm{LN})$ that presented low values, is presumably related to the input of material with low $\mathrm{Rh}$ concentrations. This suggests that the industrial source at BRR has added to the estuary increased levels of $\mathrm{Pt}$ in comparison to $\mathrm{Rh}$. At the other sites, the industrial activities supplied both elements to the sediments, lowering the $\mathrm{Pt} / \mathrm{Rh}$ ratio.

\section{Conclusions}

Platinum and Rh spatial distributions in superficial sediments of the Tagus estuary were assessed and reference levels are reported. Reference levels for Pt are close to the background, however Rh was ca. 5 times higher than its estimated crustal abundance. The main sources of these metals were confirmed, in particular those from cars and industries through their use as catalysts. Motorway bridges are a relevant via for the entrance of $\mathrm{Pt}$ and $\mathrm{Rh}$ into the estuary. The extent of this contribution relies on the structural characteristics and extension of the bridges. Even though, the $\mathrm{Pt} / \mathrm{Rh}$ ratio found in sediments does not clearly reflect that typical of automotive catalytic converters. The highest contamination levels were found in industrialised areas, revealing the important 
contribution of industrial activities. The magnitude of those emissions remains unclear and needs further evaluation because they may be dominant. This work stands as reference information for future studies and highlights the importance of understanding Pt and Rh biogeochemistry in hydrodynamic estuaries, for which the lack of knowledge remains. Platinum and $\mathrm{Rh}$ concentrations will likely increase and medium-term monitoring of those elements is recommended.

\section{Acknowledgements}

Carlos E. Monteiro (CEM) acknowledges the Portuguese Foundation for Science and Technology (FCT) for the grant funding of his $\mathrm{PhD}$ (SFRH/BD/111087/2015). The authors would like to gratefully acknowledge also the support of FCT projects UID/QUI/001002013 and PTDC/QEQ-EPR/1249/2014 'Recovery versus environmental impacts of Rare Earth Elements derived from human activities' (REEuse); the COST Action TD1407 - Network on Technology-Critical Elements (NOTICE) - from environmental processes to human health threats, by means of a short term scientific mission support to CEM; and the support of Rute Cesário in part of the field work and ICP-MS analysis.

\section{References}

Almécija, C., Cobelo-García, A., \& Santos-Echeandía, J. (2016a). Improvement of the ultra-trace voltammetric determination of $\mathrm{Rh}$ in environmental samples using signal transformation. Talanta, 146, 737-743. doi:10.1016/j.talanta.2015.06.032

Almécija, C., Cobelo-García, A., Santos-Echeandía, J., \& Caetano, M. (2016b). Platinum in salt marsh sediments: Behavior and plant uptake. Marine Chemistry, 185, 91-103. doi:10.1016/j.marchem.2016.05.009

Almécija, C., Sharma, M., Cobelo-García, A., Santos-Echeandía, J., \& Caetano, M. (2015). Osmium and platinum decoupling in the environment: Evidences in 
intertidal sediments (Tagus Estuary, SW Europe). Environmental Science and Technology, 49(11), 6545-6553. doi:10.1021/acs.est.5b00591

Alvera-Azcárate, a., Ferreira, J. G., \& Nunes, J. P. (2003). Modelling eutrophication in mesotidal and macrotidal estuaries. The role of intertidal seaweeds. Estuarine, Coastal and Shelf Science, 57(4), 715-724. doi:10.1016/S0272-7714(02)00413-4

Arpentinier, P., Koenig, J., \& Vlaming, R. (1998, April 8). Nitric acid production. Google Patents.

Birke, M., Rauch, U., Stummeyer, J., Lorenz, H., \& Keilert, B. (2017). A review of platinum group element (PGE) geochemistry and a study of the changes of PGE contents in the topsoil of Berlin, Germany, between 1992 and 2013. Journal of Geochemical Exploration. doi:https://doi.org/10.1016/j.gexplo.2017.09.005

Brito, P., Prego, R., Mil-Homens, M., Caçador, I., \& Caetano, M. (2018). Sources and distribution of yttrium and rare earth elements in surface sediments from Tagus estuary, Portugal. Science of The Total Environment, 621, 317-325. doi:https://doi.org/10.1016/j.scitotenv.2017.11.245

Cabeçadas, L. (1999). Phytoplankton production in the Tagus estuary (Portugal). Oceanologica Acta, 22(2), 205-214. doi:https://doi.org/10.1016/S03991784(99)80046-2

Cabrita, M. T., Catarino, F., \& Vale, C. (1999). The effect of tidal range on the flushing of ammonium from intertidal sediments of the Tagus estuary, Portugal. Oceanologica Acta, 22(3), 291-302. doi:10.1016/S0399-1784(99)80053-X

Caçador, I., Costa, J. L., Duarte, B., Silva, G., Medeiros, J. P., Azeda, C., et al. (2012). Macroinvertebrates and fishes as biomonitors of heavy metal concentration in the Seixal Bay (Tagus estuary): Which species perform better? Ecological Indicators, 19, 184-190. doi:https://doi.org/10.1016/j.ecolind.2011.09.007

Caetano, M., Prego, R., Vale, C., de Pablo, H., \& Marmolejo-Rodríguez, J. (2009). Record of diagenesis of rare earth elements and other metals in a transitional sedimentary environment. Marine Chemistry, 116(1), 36-46. doi:https://doi.org/10.1016/j.marchem.2009.09.003

Cobelo-García, A., López-Sánchez, D. E., Almécija, C., \& Santos-Echeandía, J. (2013). Behavior of platinum during estuarine mixing (Pontevedra Ria, NW Iberian Peninsula). Marine Chemistry, 150, 11-18. doi:10.1016/j.marchem.2013.01.005

Cobelo-García, A., Neira, P., Mil-Homens, M., \& Caetano, M. (2011). Evaluation of the contamination of platinum in estuarine and coastal sediments (Tagus Estuary and Prodelta, Portugal). Marine Pollution Bulletin, 62(3), 646-650. doi:10.1016/j.marpolbul.2010.12.018

Costa, E. M. da. (2016). Sócio-Economia. In J. Rocha (Ed.), Atlas Digital da Área Metropolitana de Lisboa. Lisboa, Portugal: Centro de Estudos Geográficos.

Craft, C. B., Seneca, E. D., \& Broome, S. W. (1991). Loss on ignition and kjeldahl digestion for estimating organic carbon and total nitrogen in estuarine marsh soils: Calibration with dry combustion. Estuaries, 14(2), 175-179. doi:10.2307/1351691

Dare, S. A. S., Barnes, S.-J., Prichard, H. M., \& Fisher, P. C. (2011). Chalcophile and platinum-group element (PGE) concentrations in the sulfide minerals from the 
McCreedy East deposit, Sudbury, Canada, and the origin of PGE in pyrite. Mineralium Deposita, 46(4), 381-407. doi:10.1007/s00126-011-0336-9

Dung, T. T. T., Cappuyns, V., Swennen, R., \& Phung, N. K. (2013). From geochemical background determination to pollution assessment of heavy metals in sediments and soils. Reviews in Environmental Science and Bio/Technology, 12(4), 335-353. doi:10.1007/s11157-013-9315-1

Eastin, J. A. (1991, April 10). Manufacturing and using nitrogen fertilizer solutions on a farm. Google Patents.

Ek, K. H., Morrison, G. M., \& Rauch, S. (2004). Environmental routes for platinum group elements to biological materials--a review. The Science of the total environment, 334-335, 21-38. doi:10.1016/j.scitotenv.2004.04.027

Ely, J. C., Neal, C. R., Kulpa, C. F., Schneegurt, M. A., Seidler, J. A., \& Jain, J. C. (2001). Implications of Platinum-Group Element Accumulation along U.S. Roads from Catalytic-Converter Attrition. Environmental Science \& Technology, 35(19), 3816-3822. doi:10.1021/es001989s

Essumang, D. K., Dodoo, D. K., \& Adokoh, C. K. (2008). The impact of vehicular fallout on the Pra estuary of Ghana (a case study of the impact of platinum group metals (PGMs) on the marine ecosystem). Environmental Monitoring and Assessment, 145(1), 283-294. doi:10.1007/s10661-007-0037-0

European Commission. (1991). Council Directive 91/542/EEC of 1 October 1991 amending Directive 88/77/EEC on the approximation of the laws of the Member States relating to the measures to be taken against the emission of gaseous pollutants from diesel engines for use in vehicles. http://eurlex.europa.eu/eli/dir/1991/542/oj. Accessed 22 January 2018

Folk, R. L. (1954). The Distinction between Grain Size and Mineral Composition in Sedimentary-Rock Nomenclature. The Journal of Geology, 62(4), 344-359. doi:10.1086/626171

Fortunato, A. B., \& Oliveira, A. (1999). On the effect of tidal flats on the hydrodynar6ics of the Tams estuarv, 22, 31-44.

Fortunato, A., Oliveira, A., \& Baptista, A. M. (1999). On the effect of tidal flats on the hydrodynamics of the Tagus estuary. Oceanologica Acta, 22(1), 31-44. doi:https://doi.org/10.1016/S0399-1784(99)80030-9

Freire, P., Taborda, R., \& Silva, A. (2007). Sedimentary characterization of Tagus estuarine beaches (Portugal). Journal of Soils and Sediments, 7(5), 296-302. doi:10.1065/jss2007.08.243

Gaudêncio, M. J., Guerra, M. T., \& Glémarec, M. (1991). Recherches biosédimentaires sur la zone maritime de l'estuaire du Tage, Portugal: données préliminaire. In M. Elliott \& J.-P. Ducrotoy (Eds.), Estuaries and Coasts: Spatial and Temporal Intercomparisons. ECSA 19 Symposium, Caen, (pp. 11-16).

Gil, O., \& Vale, C. (1999). DDT concentrations in surficial sediments of three estuarine systems in Portugal. Aquatic Ecology, 33(3), 263-269. doi:10.1023/A:1009961901782

Hatfield, W. R., Beshty, B. S., Lee, H. C., Heck, R. M., \& Hsiung, T. M. (1987, 
November 11). Method for recovering platinum in a nitric acid plant. Google Patents.

Haus, N., Eybe, T., Zimmermann, S., \& Sures, B. (2009). Is microwave digestion using TFM vessels a suitable preparation method for Pt determination in biological samples by adsorptive cathodic stripping voltammetry? Analytica chimica acta, 635(1), 53-57. doi:10.1016/j.aca.2008.12.043

IMT. (2016). Relatório de Tráfego na Rede Nacional de Autoestradas - $4^{\circ}$ Trimestre. Lisboa, Portugal.

Jarvis, K. E., Parry, S. J., \& Piper, J. M. (2001). Temporal and Spatial Studies of Autocatalyst-Derived Platinum, Rhodium, and Palladium and Selected VehicleDerived Trace Elements in the Environment. Environmental Science \& Technology, 35(6), 1031-1036. doi:10.1021/es0001512

Kašpar, J., Fornasiero, P., \& Hickey, N. (2003). Automotive catalytic converters: current status and some perspectives. Catalysis Today, 77(4), 419-449. doi:https://doi.org/10.1016/S0920-5861(02)00384-X

Laschka, D., \& Nachtwey, M. (1997). Platinum in municipal sewage treatment plants. Chemosphere, 34(8), 1803-1812. doi:http://dx.doi.org/10.1016/S00456535(97)00036-2

Lemaire, A., Dournel, P., \& Deschrijver, P. (2014, March 13). Process for the manufacture of hydrogen peroxide. Google Patents.

Loring, D. H., \& Rantala, R. T. T. (1992). Manual for the geochemical analyses of marine sediments and suspended particulate matter. Earth-Science Reviews, 32(4), 235-283. doi:https://doi.org/10.1016/0012-8252(92)90001-A

Mateus, M., \& Neves, R. (2008). Evaluating light and nutrient limitation in the Tagus estuary using a process-oriented ecological model. Journal of Marine Engineering \& Technology, 7(2), 43-54. doi:10.1080/20464177.2008.11020213

Matys Grygar, T., \& Popelka, J. (2016). Revisiting geochemical methods of distinguishing natural concentrations and pollution by risk elements in fluvial sediments. Journal of Geochemical Exploration, 170, 39-57. doi:http://dx.doi.org/10.1016/j.gexplo.2016.08.003

Mihaljevič, M., Galušková, I., Strnad, L., \& Majer, V. (2013). Distribution of platinum group elements in urban soils, comparison of historically different large cities Prague and Ostrava, Czech Republic. Journal of Geochemical Exploration, 124, 212-217. doi:https://doi.org/10.1016/j.gexplo.2012.10.008

Mil-Homens, M., Caetano, M., Costa, A. M., Lebreiro, S., Richter, T., de Stigter, H., et al. (2013). Temporal evolution of lead isotope ratios in sediments of the Central Portuguese Margin: A fingerprint of human activities. Marine Pollution Bulletin, 74(1), 274-284. doi:https://doi.org/10.1016/j.marpolbul.2013.06.044

Mil-Homens, M., Vale, C., Raimundo, J., Pereira, P., Brito, P., \& Caetano, M. (2014). Major factors influencing the elemental composition of surface estuarine sediments: the case of 15 estuaries in Portugal. Marine pollution bulletin, 84(1-2), 135-46. doi:10.1016/j.marpolbul.2014.05.026

Mil-Homens, M., Vicente, M., Grimalt, J. O., Micaelo, C., \& Abrantes, F. (2016). 
Reconstruction of organochlorine compound inputs in the Tagus Prodelta. Science of The Total Environment, 540, 231-240. doi:https://doi.org/10.1016/j.scitotenv.2015.07.009

Miller, J., \& Miller, J. (2010). Statistics and chemometrics for analytical chemistry (6th ed.). Pearson Education Limited.

Moldovan, M., Palacios, M. A., Gómez, M. M., Morrison, G., Rauch, S., McLeod, C., et al. (2002). Environmental risk of particulate and soluble platinum group elements released from gasoline and diesel engine catalytic converters. Science of The Total Environment, 296(1), 199-208. doi:https://doi.org/10.1016/S00489697(02)00087-6

Monteiro, C. E., Cesário, R., O’Driscoll, N. J., Nogueira, M., Válega, M., Caetano, M., \& Canário, J. (2016). Seasonal variation of methylmercury in sediment cores from the Tagus Estuary (Portugal). Marine Pollution Bulletin, 104(1), 162-170. doi:https://doi.org/10.1016/j.marpolbul.2016.01.042

Monteiro, C. E., Cobelo-Garcia, A., Caetano, M., \& Correia dos Santos, M. M. (2017). Improved voltammetric method for simultaneous determination of $\mathrm{Pt}$ and $\mathrm{Rh}$ using second derivative signal transformation - application to environmental samples. Talanta, 175, 1-8. doi:10.1016/j.talanta.2017.06.067

Nygren, O., Vaughan, G. T., Florence, T. M., Morrison, G. M., Warner, I. M., \& Dale, L. S. (1990). Determination of platinum in blood by adsorptive voltammetry. Analytical chemistry, 62(15), 1637-40. doi:10.1021/ac00214a020

Paparatto, G., De, A. G., D’aloisio, R., \& Buzzoni, R. (2010, September 28). Catalyst and its use in the synthesis of hydrogen peroxide. Google Patents.

Peucker-Ehrenbrink, B., \& Jahn, B. (2001). Rhenium-osmium isotope systematics and platinum group element concentrations: Loess and the upper continental crust. Geochemistry, Geophysics, Geosystems, 2(10), n/a-n/a. doi:10.1029/2001GC000172

Prichard, H. M., \& Fisher, P. C. (2012). Identification of Platinum and Palladium Particles Emitted from Vehicles and Dispersed into the Surface Environment. Environmental Science \& Technology, 46(6), 3149-3154. doi:10.1021/es203666h

Prichard, H. M., Jackson, M. T., \& Sampson, J. (2008). Dispersal and accumulation of $\mathrm{Pt}, \mathrm{Pd}$ and $\mathrm{Rh}$ derived from a roundabout in Sheffield (UK): From stream to tidal estuary. Science of The Total Environment, 401(1), 90-99. doi:https://doi.org/10.1016/j.scitotenv.2008.03.037

Prudêncio, M. I., Braga, M. A. S., \& Gouveia, M. A. (1993). REE mobilization, fractionation and precipitation during weathering of basalts. Chemical Geology, 107(3), 251-254. doi:https://doi.org/10.1016/0009-2541(93)90185-L

Rauch, S., Hemond, H. F., Barbante, C., Owari, M., Morrison, G. M., PeuckerEhrenbrink, B., \& Wass, U. (2005). Importance of automobile exhaust catalyst emissions for the deposition of platinum, palladium, and rhodium in the northern hemisphere. Environmental science \& technology, 39(21), 8156-8162.

Rauch, S., Morrison, G. M., \& Moldovan, M. (2002). Scanning laser ablation-ICP-MS tracking of platinum group elements in urban particles. Science of The Total 

3

Rauch, S., \& Peucker-Ehrenbrink, B. (2015a). Sources of Platinum Group Elements in the Environment BT - Platinum Metals in the Environment. In F. Zereini \& C. L. S. Wiseman (Eds.), (pp. 3-17). Berlin, Heidelberg: Springer Berlin Heidelberg. doi:10.1007/978-3-662-44559-4_1

Rauch, S., \& Peucker-Ehrenbrink, B. (2015b). Sources of platinum group elements in the environment. In Platinum metals in the environment (pp. 3-17). Springer.

Rauch, S., Peucker-Ehrenbrink, B., Molina, L. T., Molina, M. J., Ramos, R., \& Hemond, H. F. (2006). Platinum Group Elements in Airborne Particles in Mexico City. Environmental Science \& Technology, 40(24), 7554-7560. doi:10.1021/es061470h

Ravindra, K., Bencs, L., \& Van Grieken, R. (2004). Platinum group elements in the environment and their health risk. The Science of the total environment, 318(1-3), 1-43. doi:10.1016/S0048-9697(03)00372-3

Ruchter, N., \& Sures, B. (2015). Distribution of platinum and other traffic related metals in sediments and clams (Corbicula sp.). Water Research, 70, 313-324. doi:http://dx.doi.org/10.1016/j.watres.2014.12.011

Ruchter, N., Zimmermann, S., \& Sures, B. (2015). Field studies on PGE in aquatic ecosystems. In Platinum Metals in the Environment (pp. 351-360). Springer.

Santos-Echeandía, J., Vale, C., Caetano, M., Pereira, P., \& Prego, R. (2010). Effect of tidal flooding on metal distribution in pore waters of marsh sediments and its transport to water column (Tagus estuary, Portugal). Marine environmental research, 70(5), 358-67. doi:10.1016/j.marenvres.2010.07.003

Schlitzer, R. (2017). Ocean Data View, odv.awi.de.

Sutherland, R. A., Pearson, G. D., Ottley, C. J., \& Ziegler, A. D. (2015). PlatinumGroup Elements in Urban Fluvial Bed Sediments-Hawaii. In Platinum Metals in the Environment (pp. 163-186). Springer.

Taborda, R., Freire, P., Silva, A., Andrade, C., \& Freitas, M. (2009). Origin and evolution of Tagus estuarine beaches. Journal of Coastal Research, SI(56), 213217.

Taylor, S. R., \& McLennan, S. M. (1995). The geochemical evolution of the continental crust. Reviews of Geophysics, 33(2), 241-265. doi:10.1029/95RG00262

Terashima, S., Katayama, H., \& Itoh, S. (1993). Geochemical behavior of Pt and Pd in coastal marine sediments, southeastern margin of the Japan Sea. Applied Geochemistry, 8(3), 265-271. doi:https://doi.org/10.1016/0883-2927(93)90041-E

Troupin, C., Barth, A., Sirjacobs, D., Ouberdous, M., Brankart, J.-M., Brasseur, P., et al. (2012). Generation of analysis and consistent error fields using the Data Interpolating Variational Analysis (DIVA). Ocean Modelling, 52-53(Supplement C), 90-101. doi:https://doi.org/10.1016/j.ocemod.2012.05.002

Vale, C., Canário, J., Caetano, M., Lavrado, J., \& Brito, P. (2008). Estimation of the anthropogenic fraction of elements in surface sediments of the Tagus Estuary 
(Portugal). Marine Pollution Bulletin, 56(7), 1364-1367. doi:https://doi.org/10.1016/j.marpolbul.2008.04.006

Vale, C., \& Sundby, B. (1987). Suspended sediment fluctuations in the Tagus estuary on semi-diurnal and fortnightly time scales. Estuarine, Coastal and Shelf Science, 25(5), 495-508. doi:http://dx.doi.org/10.1016/0272-7714(87)90110-7

Vaz, N., \& Dias, J. M. (2014). Residual currents and transport pathways in the Tagus estuary, Portugal: the role of freshwater discharge and wind. Journal of Coastal Research, 610-615. doi:10.2112/SI70-103.1

Vaz, N., Mateus, M., \& Dias, J. M. (2011). Semidiurnal and spring-neap variations in the Tagus Estuary: Application of a process-oriented hydro-biogeochemical model. Journal of Coastal Research, SI(64), 1619-1623.

Vyas, N., Turner, A., \& Sewell, G. (2014). Platinum-based anticancer drugs in waste waters of a major UK hospital and predicted concentrations in recipient surface waters. Science of The Total Environment, 493, 324-329. doi:https://doi.org/10.1016/j.scitotenv.2014.05.127

Wei, C., \& Morrison, G. M. (1994). Platinum in road dusts and urban river sediments. Science of The Total Environment, 146-147(Supplement C), 169-174. doi:https://doi.org/10.1016/0048-9697(94)90234-8

Wiseman, C. L. S., Hassan Pour, Z., \& Zereini, F. (2016). Platinum group element and cerium concentrations in roadside environments in Toronto, Canada. Chemosphere, 145, 61-67. doi:https://doi.org/10.1016/j.chemosphere.2015.11.056

Wiseman, C. L. S., \& Zereini, F. (2009). Airborne particulate matter, platinum group elements and human health: a review of recent evidence. The Science of the total environment, 407(8), 2493-2500. doi:10.1016/j.scitotenv.2008.12.057

Wiseman, C. L. S., Zereini, F., \& Püttmann, W. (2013). Traffic-related trace element fate and uptake by plants cultivated in roadside soils in Toronto, Canada. Science of The Total Environment, 442, 86-95. doi:https://doi.org/10.1016/j.scitotenv.2012.10.051

Zereini, F., Alt, F., Messerschmidt, J., von Bohlen, A., Liebl, K., \& Püttmann, W. (2004). Concentration and Distribution of Platinum Group Elements (Pt, Pd, Rh) in Airborne Particulate Matter in Frankfurt am Main, Germany. Environmental Science \& Technology, 38(6), 1686-1692. doi:10.1021/es030127z

Zereini, F., \& Wiseman, C. L. S. (2015). Platinum Metals in the Environment. (F. Zereini \& C. L. S. Wiseman, Eds.). Berlin, Heidelberg: Springer Berlin Heidelberg. doi:10.1007/978-3-662-44559-4

Zereini, F., Wiseman, C., \& Püttmann, W. (2007). Changes in Palladium, Platinum, and Rhodium Concentrations, and Their Spatial Distribution in Soils Along a Major Highway in Germany from 1994 to 2004. Environmental Science \& Technology, 41(2), 451-456. doi:10.1021/es061453s

Zhong, L., Yan, W., Li, J., Tu, X., Liu, B., \& Xia, Z. (2012). Pt and Pd in sediments from the Pearl River Estuary, South China: background levels, distribution, and source. Environmental Science and Pollution Research, 19(4), 1305-1314. doi:10.1007/s11356-011-0653-7 


\section{Caption of figures}

Fig. 1 Map representation of the study area location, the Tagus estuary, SW Europe. Bathymetric data in meters (obtained from the Portuguese Hydrographic Institute; http://www.hidrografico.pt) with depicted stations where superficial sediments were collected (white dots); (25A) 25 de Abril bridge; (VG) Vasco da Gama bridge (area in dashed line); Industrialised areas (CN, LN, SN and BRR, in circles); WWTP: (A) Alcântara, (B) Beirolas and (C) Chelas; and pluvial waters discharge (TP) Terreiro do Paço. Most relevant stations and the Natural Reserve area of the estuary are also indicated.

Fig. 2 Spatial distribution of $\mathrm{Pt}$ and $\mathrm{Rh}$ concentrations, in $\mathrm{ng} \mathrm{g}^{-1}$, in superficial sediments of Tagus estuary.

Fig. 3 Boxplot of (a) median and total concentrations ( $\mathrm{ng} \mathrm{g}^{-1}$ ) of Pt and Rh in superficial sediments of Tagus estuary; (b) Pt and (c) Rh concentrations depicted by section, respectively; (d) Rh concentrations depicted in industry section. Significant differences amongst groups were observed (Kruskal-Wallis $(H)$ test; $\mathrm{p}<0.05)$ and are indicated by different letters (Mann-Whitney $(U)$ test; $\mathrm{p}<0.05$ ).

Fig. 4 Bivariate plots between $\mathrm{Pt}$ and $\mathrm{Rh}$ with $\mathrm{Al}, \mathrm{LOI}$ and Fe in superficial sediments of Tagus estuary. (๑) background in the estuary; (○) waste-and pluvial waters discharges; ( $\square) V G$ bridge; and $(\diamond)$ industrialised areas. The dashed line represents the trends found in the background data and the Spearman correlations $\left(\mathrm{r}_{\mathrm{S}}\right)$ found, respectively. 
Fig. 5 Spatial distributions of $\mathrm{Pt}$ and $\mathrm{Rh}$ with concentrations normalised to $\mathrm{Al}$, LOI and Fe in superficial sediments of Tagus estuary.

Fig. 6 (a) Pt and (b) Rh concentrations normalised to Al and LOI from WWTP discharge sites (A) Alcântara, (B) Beirolas and (C) Chelas, and pluvial- waters discharge site (TP) Terreiro do Paço, and respective control stations in superficial sediments from Tagus estuary: Alcântara upstream (A-U) and downstream (A -D); Beirolas upstream (B-U) and downstream (B -D), Chelas upstream (C-U) and downstream (C-D), and Terreiro do Paço upstream (TP-U) and downstream (TP -D). (*) Data not presented due to an outlier value of LOI.

Fig. 7 Signature of $\mathrm{Pt}$ and $\mathrm{Rh}$ in superficial sediments of Tagus estuary. The $\mathrm{Pt} / \mathrm{Rh}$ range varied between 0.48 and 39, with the highest values found at BRR stations. 


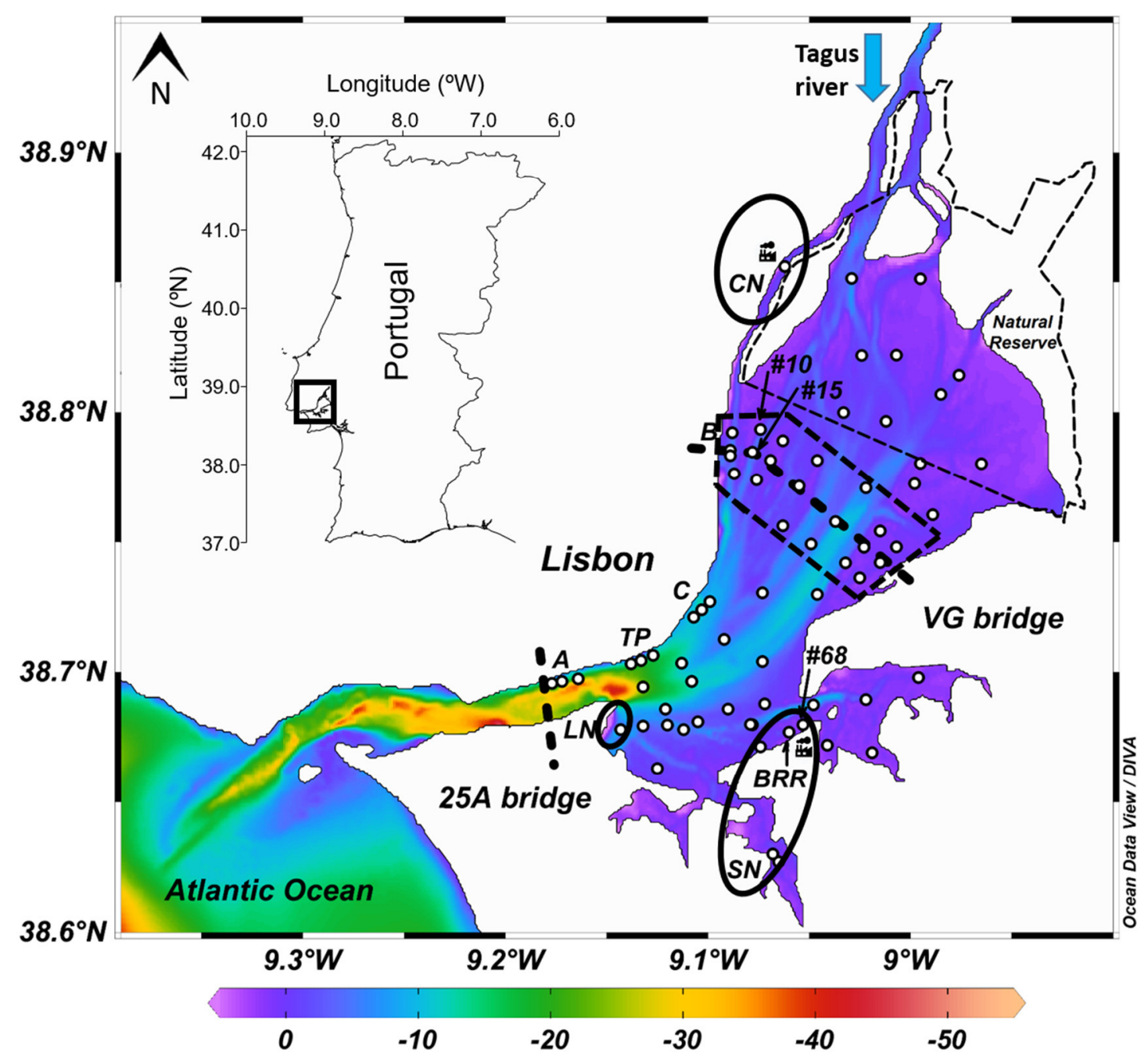




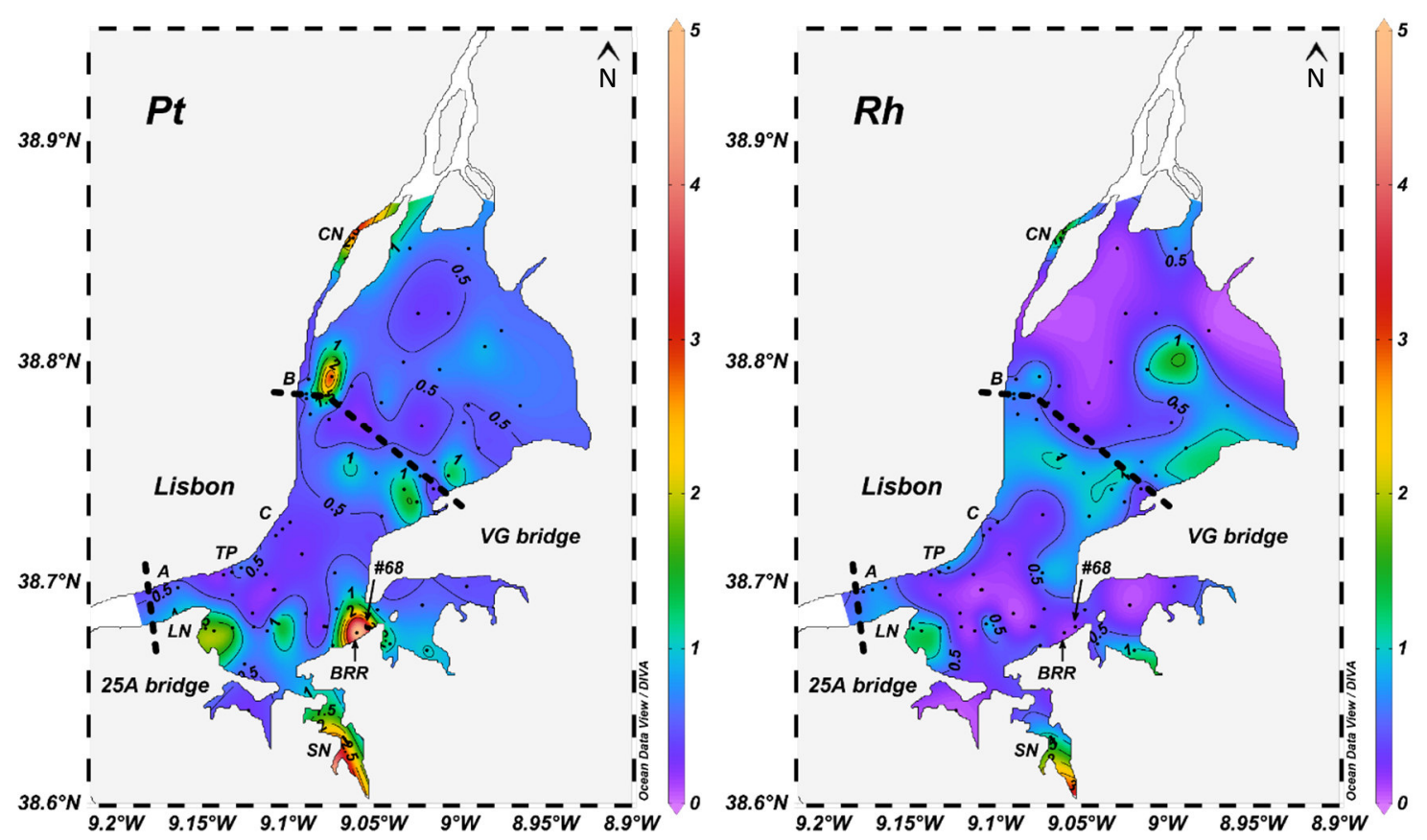



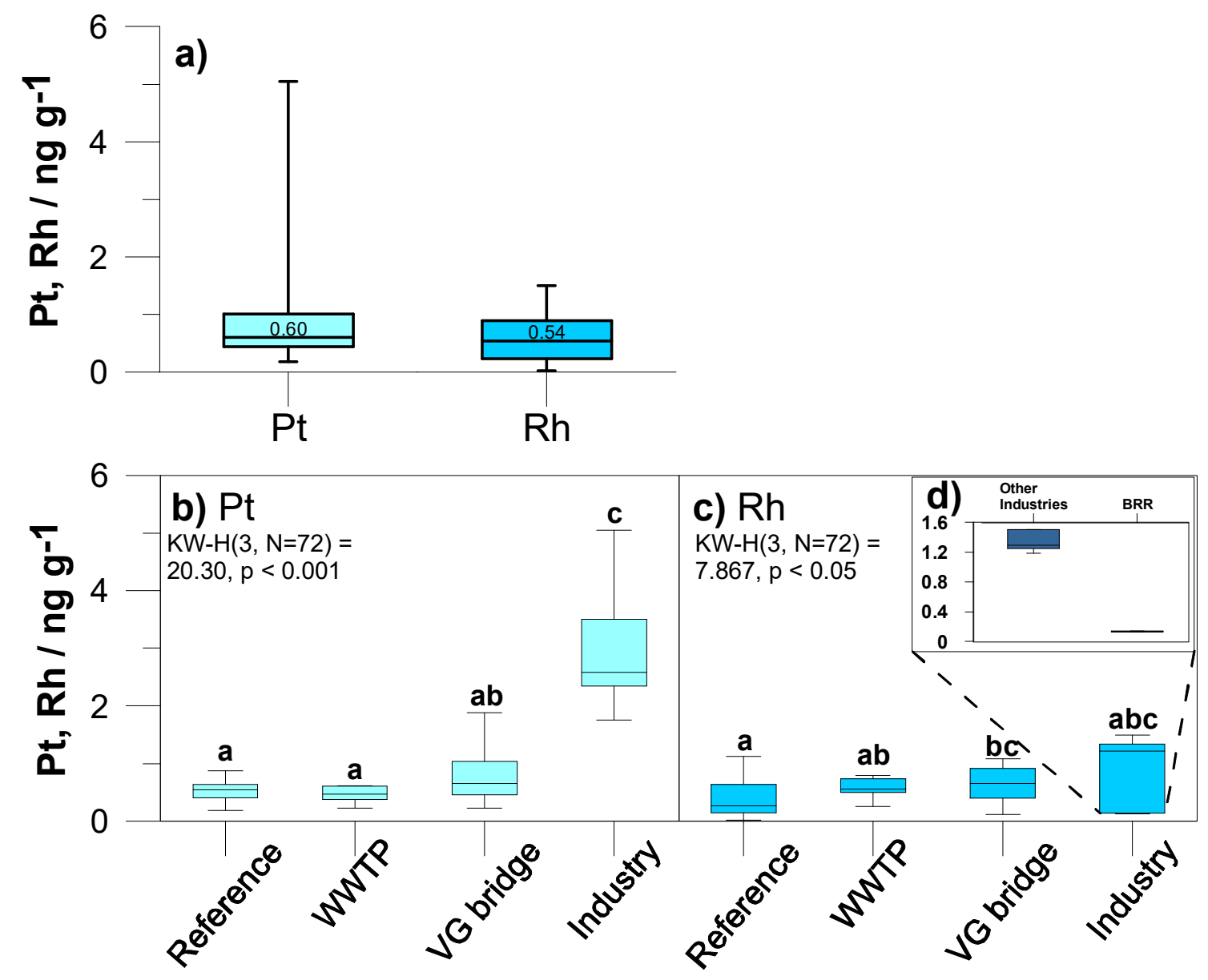

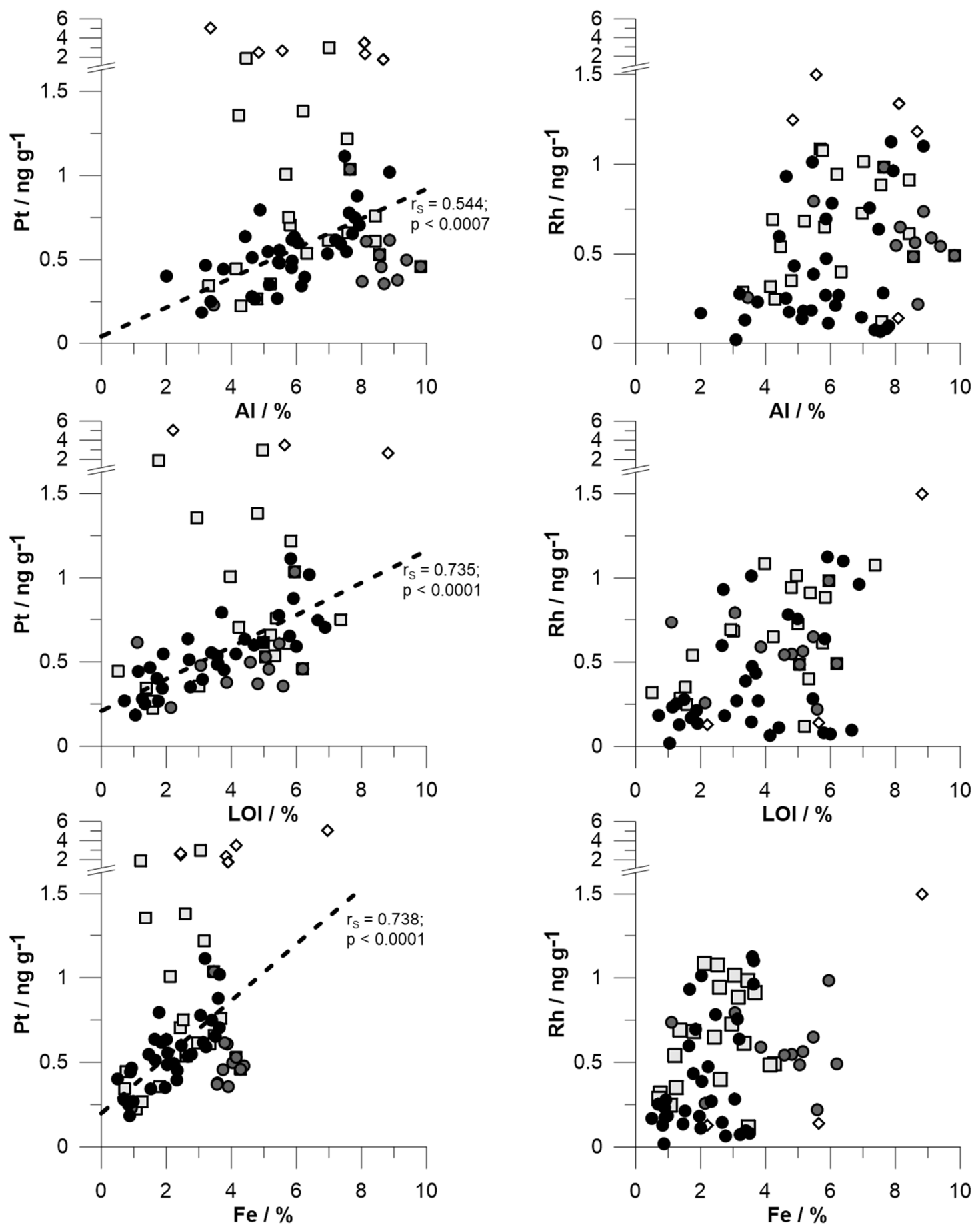


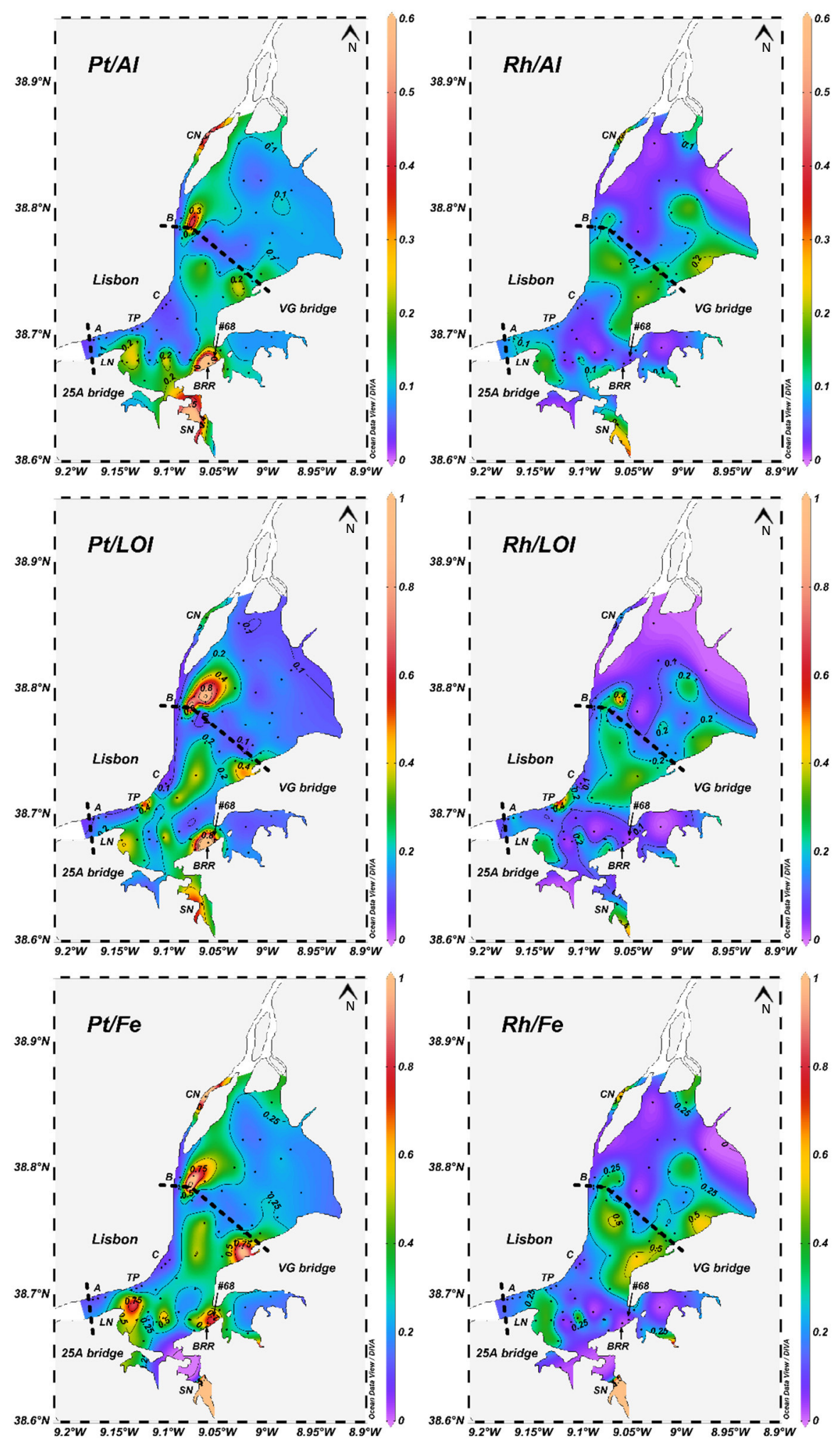



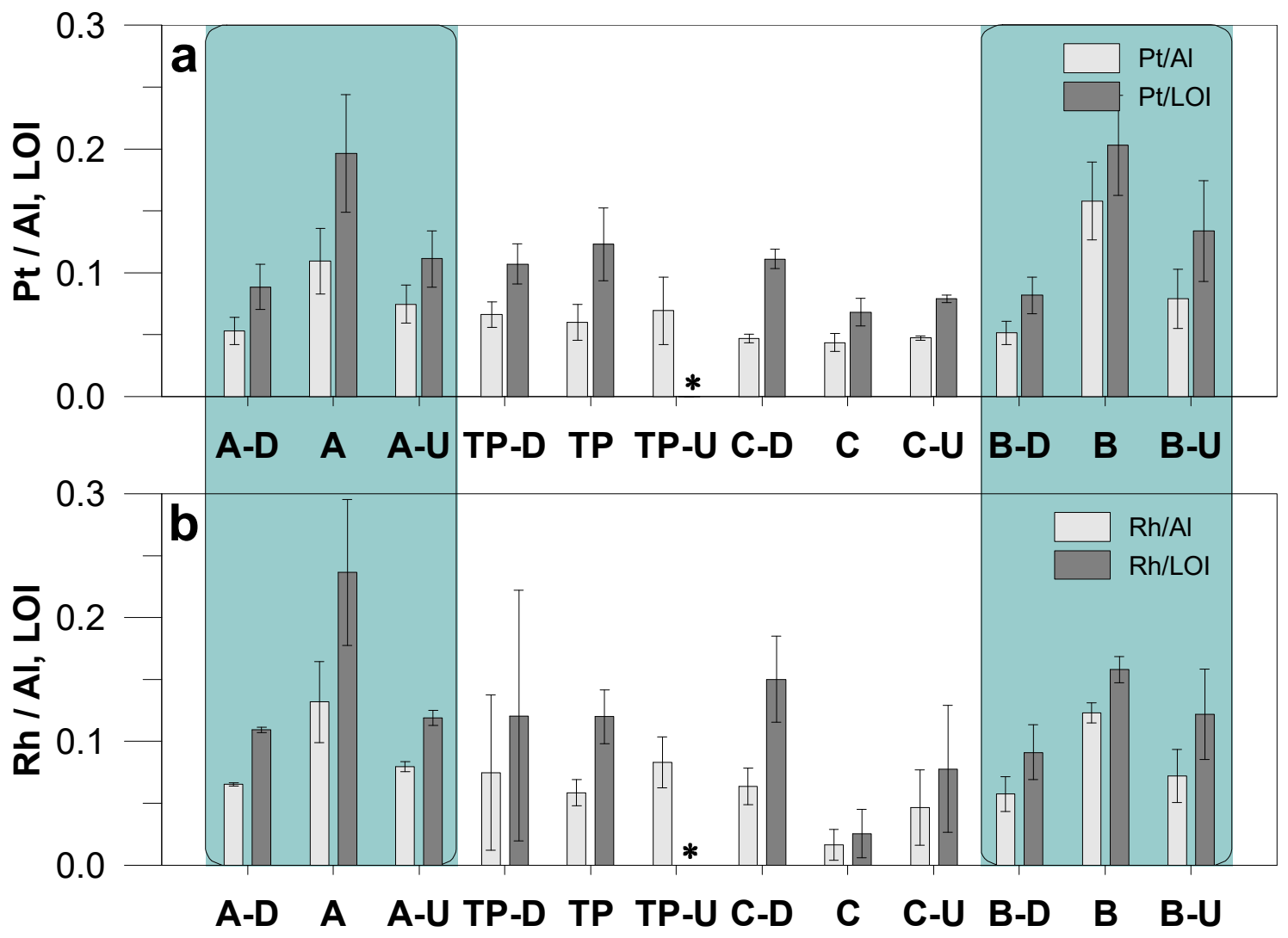


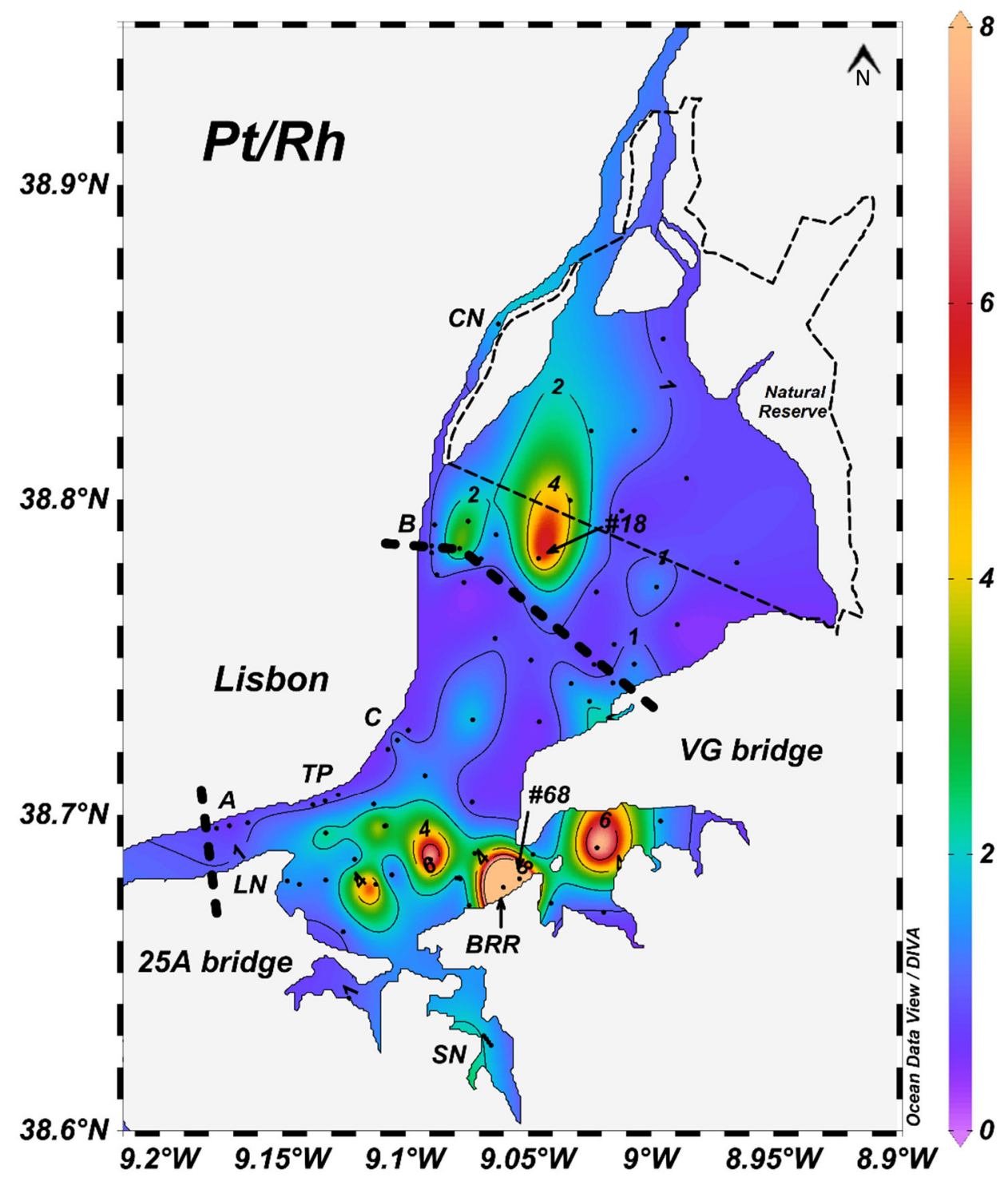


Table 1 Descriptive statistics of the parameters used in the characterisation of the superficial sediments of Tagus estuary.

\begin{tabular}{|c|c|c|cccccc|}
\cline { 2 - 9 } \multicolumn{1}{c|}{} & Units & $\mathbf{n}$ & Min & $\begin{array}{c}\mathbf{1}^{\text {st }} \\
\text { Quartile }\end{array}$ & Median & Mean & $\begin{array}{c}3^{\text {rd }} \\
\text { Quartile }\end{array}$ & Max \\
\hline $\mathrm{Al}$ & $\%$ & 72 & 2.0 & 4.8 & 6.0 & 6.2 & 7.7 & 9.8 \\
$\mathrm{Fe}$ & $\%$ & 72 & 0.50 & 1.6 & 2.5 & 2.6 & 3.6 & 7.0 \\
$\mathrm{Mn}$ & $\%$ & 70 & 0.010 & 0.023 & 0.030 & 0.033 & 0.041 & 0.71 \\
$\mathrm{Mg}$ & $\%$ & 70 & 0.16 & 0.49 & 0.80 & 0.76 & 1.0 & 1.4 \\
$\mathrm{Ca}$ & $\%$ & 70 & 0.01 & 0.49 & 1.2 & 1.7 & 2.5 & 7.1 \\
Sand & $\%$ & 57 & 2.4 & 15 & 41 & 42 & 64 & 98 \\
Silt + Clay & $\%$ & 57 & 2.1 & 34 & 59 & 57 & 85 & 98 \\
LOI & $\%$ & 72 & 0.51 & 2.2 & 3.9 & 3.9 & 5.4 & 8.8 \\
\hline
\end{tabular}




\section{SUPPORTING INFORMATION}

\section{Platinum and Rhodium in Tagus Estuary, SW Europe: sources and spatial distribution}

Carlos Eduardo Monteiro ${ }^{1,2 *}$, Margarida Correia dos Santos ${ }^{2}$, Antonio Cobelo-Garcia ${ }^{3}$, Pedro Brito ${ }^{1}$ and Miguel Caetano ${ }^{1}$

${ }^{1}$ IPMA-Portuguese Institute of Sea and Atmosphere, Division of Oceanography and Marine Environment, Av. Brasília, 1449-006 Lisbon, Portugal

2 Environmental Biogeochemistry, Centro de Química Estrutural, Instituto Superior Técnico, Universidade de Lisboa, Av. Rovisco Pais 1, 1049-001, Lisboa, Portugal

3 Bioxeoquímica Mariña, Instituto de Investigacións Mariñas IIM-CSIC, Eduardo Cabello 6, 36208 Vigo, Pontevedra, Spain

*Corresponding author: Carlos E. Monteiro:

carlos.monteiro@ipma.pt

carlos.e.monteiro@tecnico.ulisboa.pt

IPMA-Instituto português do Mar e da Atmosfera, Divisão de Oceanografia e Ambiente Marinho, Av. Brasília, 1449-006 Lisboa, Portugal $+351218447000$

Centro de Química Estrutural, Instituto Superior Técnico, Universidade de Lisboa, Av. Rovisco Pais 1, Torre Sul Lab 11.6-2, 1049-001, Lisboa, Portugal 


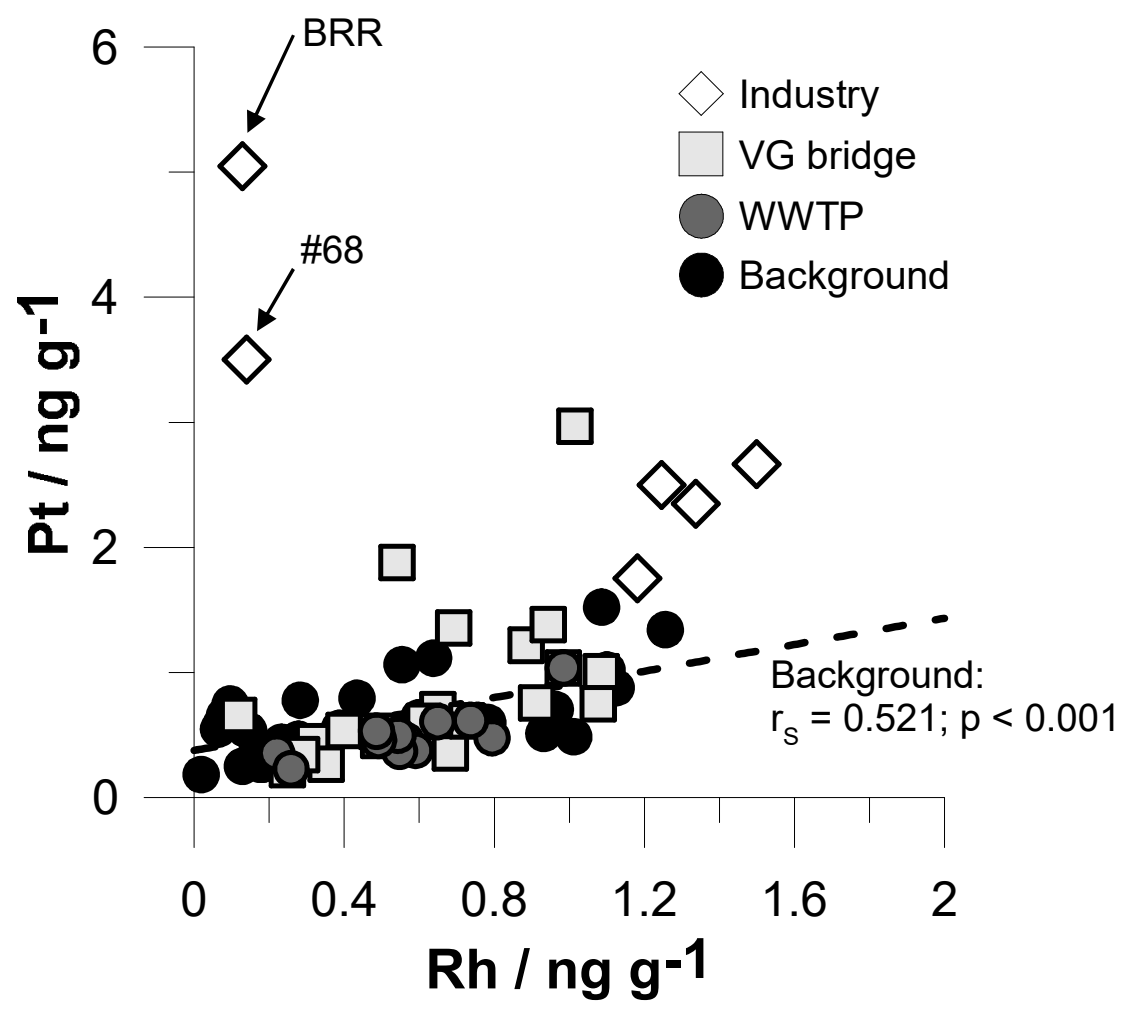

S.I. Fig. 1 Bivariate plot of $\mathrm{Pt}$ and $\mathrm{Rh}$ in superficial sediments of Tagus estuary, depicted by section; trend on the background data and the respective Spearman correlation $\left(\mathrm{r}_{\mathrm{s}}\right)$ are represented by the dashed line. 


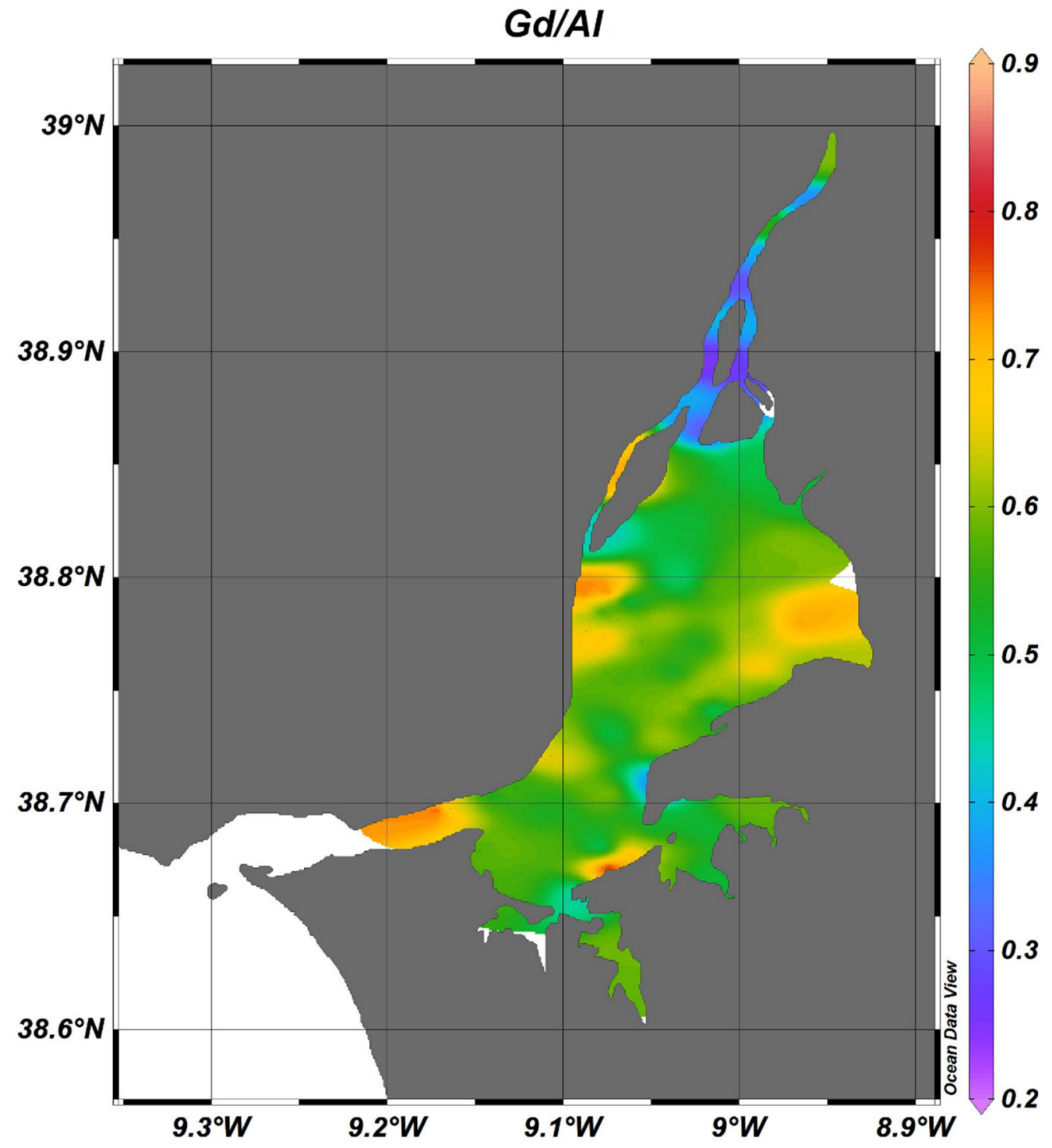

S.I. Fig. 2 Spatial distribution of Gd concentrations normalised to $\mathrm{Al}$ in superficial sediments of Tagus estuary. 


\section{Estimation of Pt and Rh emissions}

Using the same approach as in Almécija et al. (2015), we estimated the range of Pt and Rh emissions from ACC in VG and 25A bridges. Table A.1 summarises the calculations based on: (i) minimum and maximum number of vehicles per day crossing the bridges in one year period (2015/2016) before the sampling (IMT 2016); (ii) the deck lengths: 17.2 $\mathrm{km}$ long for $\mathrm{VG}$ bridge and $2.3 \mathrm{~km}$ for $25 \mathrm{~A}$ bridge (www.lusoponte.pt); (iii) the proportion of gasoline engine vehicles to diesel engine that is approximately 4:6 (ACEA 2017); (iv) the range of estimated release of $\mathrm{Pt}$ and $\mathrm{Rh}$ from $\mathrm{ACC}$ at a rate of $\mathrm{ng} \mathrm{km} \mathrm{km}^{-1}$ (Palacios et al. 2000); and (v) the number of days calculated since the opening of VG bridge until the sampling campaign (6631 days), as well as for 25A bridge for comparison purposes. Almécija et al. (2015) has estimated that nearly 450 and $1140 \mathrm{~g}$ of Pt has been released over 13 years since the opening of VG bridge, using two different approaches. Our estimation of total emissions ranged from $542-937 \mathrm{~g}$ of Pt and $130-262 \mathrm{~g}$ of $\mathrm{Rh}$ in VG bridge, while for 25A bridge were $171-312 \mathrm{~g}$ of Pt and $41-87 \mathrm{~g}$ of $\mathrm{Rh}$, since the opening of VG bridge in 1998.

Table A.1 - Estimation of Pt and Rh range of emissions in Vasco da Gama (VG) bridge and 25 de Abril (25A) bridge since the opening of VG bridge.

\begin{tabular}{|c|c|}
\hline \multicolumn{2}{|c|}{ Vasco da Gama (VG) bridge } \\
\hline Beginning of activity & April 1998 \\
\hline Sampling for this work & June 2016 \\
\hline Estimated number of days & 6631 \\
\hline $\begin{array}{r}\text { Vehicles traffic / day - 1 year previous } t \\
\text { min } \\
\max \end{array}$ & pling \\
\hline Extension of the bridge & $17.2 \mathrm{~km}$ \\
\hline 25 de Abril & A) bridge \\
\hline
\end{tabular}




\begin{tabular}{|c|c|c|c|c|}
\hline Beginning of activity & & previous to 1990 & & \\
\hline Sampling for this work & & June 2016 & & \\
\hline Estimated number of days & & 9125 & & \\
\hline \multicolumn{5}{|c|}{ Vehicles traffic / day - 1 year previous to sampling } \\
\hline & $\min$ & 125649 & & \\
\hline & $\max$ & 152957 & & \\
\hline Extension of the bridge & & 2.3 & $\mathrm{~km}$ & \\
\hline \multicolumn{5}{|c|}{ For comparison purposes, $n^{0}$ days in calculations: 6631} \\
\hline Diesel vehicles $^{\mathbf{a}}$ & 65 & $\%$ & & \\
\hline Petrol vehicles ${ }^{\mathbf{a}}$ & 35 & $\%$ & & \\
\hline New vehicles ${ }^{\mathbf{a}}$ & 7 & $\%$ & & \\
\hline Old vehicles ${ }^{\mathbf{a}}$ & 93 & $\%$ & & \\
\hline \multicolumn{5}{|c|}{ Estimated range of $\mathrm{Pt}$ emissions ${ }^{\mathrm{b}}$} \\
\hline & & & $\min$ & $\max$ \\
\hline \multicolumn{5}{|l|}{ Petrol } \\
\hline New vehicles & $\mathrm{ng} \mathrm{M} / \mathrm{km}$ & & 102 & \\
\hline Old vehicles & $\mathrm{ng} \mathrm{M} / \mathrm{km}$ & & 6.3 & -8.2 \\
\hline \multicolumn{5}{|l|}{ Diesel } \\
\hline New vehicles & $\mathrm{ng} \mathrm{M} / \mathrm{km}$ & & 404 & -812 \\
\hline Old vehicles & $\mathrm{ng} \mathrm{M} / \mathrm{km}$ & & 110 & -152 \\
\hline VG bridge TOTAL & $\mathrm{gPt}$ & & 542 & -937 \\
\hline 25A bridge TOTAL & g Pt & & 171 & -312 \\
\hline \multicolumn{5}{|c|}{ Estimated range of $\mathbf{R h}_{\text {emissions }}{ }^{b}$} \\
\hline & & & $\min$ & $\max$ \\
\hline \multicolumn{5}{|l|}{ Petrol } \\
\hline New vehicles & $\mathrm{ng} \mathrm{M} / \mathrm{km}$ & & 38 & -66 \\
\hline Old vehicles & $\mathrm{ng} \mathrm{M} / \mathrm{km}$ & & 3.7 & -12 \\
\hline \multicolumn{5}{|l|}{ Diesel } \\
\hline New vehicles & $\mathrm{ng} \mathrm{M} / \mathrm{km}$ & & 82 & -184 \\
\hline Old vehicles & $\mathrm{ng} \mathrm{M} / \mathrm{km}$ & & 26 & -39 \\
\hline VG bridge TOTAL & $\mathbf{g} \mathbf{R h}$ & & 130 & -262 \\
\hline
\end{tabular}


${ }^{a}$ Estimated from Instituto Nacional de Estatística and http://www.acea.be/statistics/

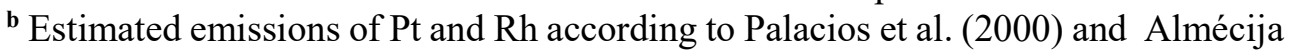
et al. (2015).

\section{References}

ACEA. (2017). Vehicles in use - Europe 2017. Brussels, Belgium.

Almécija, C., Sharma, M., Cobelo-García, A., Santos-Echeandía, J., \& Caetano, M. (2015). Osmium and platinum decoupling in the environment: Evidences in intertidal sediments (Tagus Estuary, SW Europe). Environmental Science and Technology, 49(11), 6545-6553. doi:10.1021/acs.est.5b00591

IMT. (2016). Relatório de Tráfego na Rede Nacional de Autoestradas - $4^{o}$ Trimestre. Lisboa, Portugal.

Palacios, M. A., Gómez, M. M., Moldovan, M., Morrison, G., Rauch, S., McLeod, C., et al. (2000). Platinum-group elements: quantification in collected exhaust fumes and studies of catalyst surfaces. Science of The Total Environment, 257(1), 1-15. doi:https://doi.org/10.1016/S0048-9697(00)00464-2 